\title{
Mission Impossible? Socio-Technical Integration of Nuclear Waste Geological Disposal Systems
}

\author{
François Diaz-Maurin $1,2, * \mathbb{C}$ and Rodney C. Ewing ${ }^{1,3}$ \\ 1 Center for International Security and Cooperation (CISAC), Stanford University, Stanford, CA 94305, USA; \\ rewing1@stanford.edu \\ 2 Amphos 21 Consulting S.L., C/Venezuela 103, 08019 Barcelona, Spain \\ 3 Department of Geological Sciences, Stanford University, Stanford, CA 94305, USA \\ * Correspondence: fdm@stanford.edu; Tel.: +1-650-725-2702
}

Received: 3 November 2018; Accepted: 20 November 2018; Published: 24 November 2018

check for updates

\begin{abstract}
We present a new perspective on geological disposal systems for nuclear waste. Geological disposal systems encompass all the processes required for the permanent isolation of highly-radioactive materials from humans and the biosphere. Radioactive materials requiring geological disposal are created by commercial nuclear power plants, research reactors, and defense-related nuclear activities, such as spent nuclear fuel from commercial reactors and high-level waste from reprocessing to reclaim fissile material for weapons. We show that disposal systems are so complex that new methods of representation are required. Despite the common call for a systems approach, a broader perspective is needed to obtain an integrated view of disposal systems. We introduce a conceptual formalism of geological disposal systems based on a multi-scale integrated analysis approach. This 'metabolic' representation allows one to account for the technical complexity of disposal systems in relation to their broader societal context. Although the paper is conceptual, the integrated formalism can improve the understanding of the complexity of disposal systems and their policy requirements by connecting technical solutions with societal constraints. However, the paper also reveals the limits to efforts to integrate technical and social dimensions of geological disposal systems into a single formalism.
\end{abstract}

Keywords: radioactive waste; spent nuclear fuel; high-level waste; transuranic waste; geological disposal; repository design; Yucca Mountain; WIPP; integrated analysis; knowledge organization; complex systems; science-policy

\section{Introduction}

Technologists continue to search for "quick" solutions to the safe, long-term management of nuclear waste. However, despite decades of scientific research, engineering analysis and policy formulation efforts, worldwide, only one geologic repository currently accepts radioactive waste-the Waste Isolation Pilot Plant (WIPP) in New Mexico, United States. Despite progress in some countries like Finland, Sweden, and France, national efforts to site geologic repositories for nuclear waste have generally have encountered strong opposition [1]. Thus, there is a need for further research effort in understanding the structure of disposal systems based on new perspectives and methods. In fact, although the global nuclear waste disposal stalemate affects countries differently, based on specific technical, scientific, political, legal and even cultural factors, we hypothesize that at least part of the problem comes from an underestimation and a misconception of the complexity of the process of disposing of radioactive materials whose inventory changes over time in evolving geologic conditions. This misconception occurs at both the technical and policy levels. At the technical level, scientists and experts tend to overestimate the capacity of society to accept their proposed technical solutions, 
however scientifically sound. At the policy level, the nuclear waste problem often has been considered to be "simple" and even, as Robert Oppenheimer, Chairman of the Atomic Energy Commission's General Advisory Committee, once said, "unimportant" ([2], p. 3).

A recent example can be found in an editorial in Nature [3], which suggested that a portion of the U.S. Department of Energy (DOE)'s high-level waste (HLW), resulting from reprocessing to obtain fissile material, should be reclassified as transuranic waste so that the "reclassified" waste can be disposed of at the WIPP in New Mexico. According to the editorial, extending the authorized operations of WIPP "could make disposal simpler and cheaper", especially as it is not clear whether the proposed geologic repository at Yucca Mountain, Nevada, will ever be constructed [4]. The reclassification of the HLW would accelerate the clean-up of the U.S. DOE's Hanford Site in Washington State, where leaking underground storage tanks of HLW contaminate the groundwater. Yet, DOE's disposition problem cannot be resolved by simply "changing the label" of some waste materials as the Nature editorial suggests. Rather, the safe disposal of defense HLW in the U.S. requires specific management procedures and regulations, all of which translate into specific technical considerations. Specifically, reclassifying defense HLW into transuranic (TRU) waste for their disposal at WIPP would require addressing in detail technical, management and materials' control, which have not been considered in the current design and operation license at WIPP. As a result, the safety assessment of the repository, as well as the waste acceptance criteria would need to be thoroughly revised if defense HLW were to be disposed at WIPP (see Section 3.3.3). This example shows how policy discussions about disposal strategies can suffer from oversimplifications about the nature of disposal systems. Yet, experience has proven that simple "solutions" arrived at effortlessly then failed in the face of technical and social issues suggest that disposal systems are more complex than appreciated.

To design effective nuclear waste disposal strategies and policies, a science-policy framework is required that completely describes proposed technical solutions and connects these solutions to their associated societal dimensions. This requires a representation of the entire disposal system, from the point of waste generation to its final disposal, considering all relevant technical dimensions. The need for an evaluation of the overall system is generally recognized $[5,6]$. For instance, efforts have been made for building unified information systems of radioactive materials at the point of waste generation [7-9], integrating the back-end of the nuclear fuel cycle in the U.S. [10,11], and conducting multi-criteria performance assessments of various nuclear fuel cycle options [12,13]. However, there has been no formalization of disposal systems from an integrated perspective, beyond the conventional risk-based systems approach of engineering assessments [14-18].

This paper presents a conceptual, integrated formalism that could be used to represent disposal systems from a technically complete, societal perspective. Section 2 summarizes the complexity of the back-end of the nuclear fuel cycle, discusses its implications for the representation of disposal systems, and introduces the multi-scale approach on which the integrated formalism will be based. Section 3 presents the general integrated formalism proposed for the technically complete description of disposal systems, presents an example of application in the context of the proposed repository at Yucca Mountain in the United States, and extends the formalism to societal constraints. Section 4 discusses the value and limitations of the integrated formalism in the analysis of disposal systems and policies. Section 5 summarizes the main conclusions.

\section{Materials and Methods}

\subsection{The Complexity of Geological Disposal Systems}

The complexity of deep geological disposal systems resides in the multiple interactions that exist between the various attributes outside and inside the systems across large temporal and spatial scales. The complex nature of disposal systems implies several methodological challenges for an integrated analysis. Disposal systems are massive and unavoidably succumb to effects from the society outside of the nuclear power sector and defense programs. Second, disposal systems 
are integral, including changes from waste generation to final disposal. Lastly, disposal systems are complex both internally (non-linear relations between attributes) and externally (interactions between attributes and external factors). The complexity of disposal systems can arise from the evolving waste properties, the variety of waste streams, changing environmental and societal conditions, and the possible interactions between all these factors. In this paper, we mainly focus on the technical complexity that affects geological disposal systems. Technical complexity refers to the relations involving thermal, mechanical, chemical, geologic, hydrologic and nuclear processes at the level of the repository, as well as the exogenous natural processes, such as seismic activity, volcanism and climate change, involved at the level of the biosphere and the lithosphere.

The various complex relations that affect geological disposal systems at the technical level can be described using the following logical framework:

- A wide variety of radioactive waste types exists depending on the different types of military and civilian applications of nuclear energy. Radioactive waste that require geologic disposal are highly radioactive, heat-producing waste. Such radioactive waste materials generally include spent nuclear fuels (SNF) and HLW regardless of origin; although there are some exceptions such as in the U.S. where greater-than-class C (GTCC) and TRU waste also require geologic disposal. Changes in the waste streams will affect the waste types that must be handled which, in turn, may generate constraints on the feasibility of proposed changes at the waste generation points.

- The composition of the waste (e.g., activation products, mixed fission products, transuranic radionuclides) changes as a function of time due to radioactive decay, and the resulting change in composition drives the changes in the thermal output and the type and intensity of the radiation field [19]. In addition, the different compositions of the waste experience different types of treatment and conditioning (e.g., reprocessing, vitrification, incineration) which, in turn, modify the properties of the waste. For instance, "reprocessing lowers the content of long-lived actinides, but leaves high concentrations of shorter-lived fission products, such as Cs-137 and Sr-90, which have half-lives of approximately 30 years and hence a large thermal output. This heat in turn determines how long the waste must be stored at the surface before [geologic] disposal" ([20], p. 235). In addition, the processing that creates HLW involves a very complicated chemistry that includes elements that are not radioactive, such as $\mathrm{Pb}$ and $\mathrm{Hg}$, as well as organic solvents, that will also affect the properties of the waste.

- Waste packages are defined by different types of waste forms (e.g., untreated SNF, glass, ceramics, synroc) associated with different types of metal canisters which, in turn, affect the evolution of the waste forms. For instance, corroded iron containers may adsorb radionuclides on the surfaces of fine-grained iron oxides making the corrosion products a barrier, thus lowering the mobility of radionuclides even when the canister is breached.

- Depending on the repository design strategy, the type of overpack or surrounding backfill varies or is absent, which, in turn, affects the evolution of the waste form, in particular during the thermal period.

- The geological conditions are different (e.g., variations in redox conditions and hydrology), defining the mobility of the radionuclides which, in turn, depends on the evolving properties, composition of the waste and associated level of radioactivity.

- Various other complex relations exist outside the thermal, mechanical, chemical, geologic and hydrologic and nuclear processes, but nevertheless affect the repository behavior. Exogenous processes concern the possibility of seismic activity, volcanism, erosion, and glaciation. These exogenous processes can affect the geological conditions at the repository. Exogenous processes also concern the possibility of human intrusion in the future (e.g., exploration for natural resources), although the intrusion scenarios are generally defined by the regulators, and thus, are imposed as an external boundary condition on the disposal system (see Section 3.3). 
In summary, the technical complexity of nuclear disposal systems is driven by the evolving properties (e.g., composition and thermal output), which affect the near-field geological conditions, which in turn affect the evolving geologic conditions and the mobility of radionuclides across the engineered and geologic barriers. In addition, the near-field geological conditions themselves are affected by the probability of exogenous processes. As one can understand, there are multiple interactions between the engineered and geological barriers defining the containment strategy of different repository concepts [20-25]. These highly-coupled interactions require an analysis of the entire disposal system.

\subsection{Representations of Geological Disposal Systems}

We show in this section how the engineering representation is not sufficient to account for the complexity of geological disposal systems. Rather, the methodological challenges discussed above require the adoption of a complex systems approach when representing such systems. The complexity of geological disposal can be better accounted for by formalizing the systems by an integrated analysis approach based on a metabolic representation of its various technical attributes [26,27].

\subsubsection{Engineering Representation}

Geological disposal systems are generally conceptualized using a deterministic approach. However, the methodology to demonstrate compliance with post-closure standards of geological repositories relies, particularly in the U.S., on probabilistic calculations [28,29]. In the case of the Yucca Mountain repository in the U.S., for example, compliance is demonstrated using a probabilistic total system performance assessment (TSPA) [30]. To account for complexity in performance assessment, the strategy relies on a hierarchical organization of sub-models, which account for about 300 sub-models in the TSPA supporting the license application of the Yucca Mountain repository [30]. Yet, such a strategy relies on a weak conceptualization of complexity and hierarchy, simply referring to complexity as the existence of non-linearity in systems and using hierarchies only for data management purposes, without a consideration of the issue of scale in the analysis. The issue of scale, although very important in quantitative analysis of sustainability [31], is often ignored in the engineering representations that seek to discuss the complexity of systems. In this view where models are developed one scale at a time [32], complexity is reduced to its computational form, ignoring the non-linear relations that exist between the various functional scales that characterize self-modifying complex systems $[33,34]$. We show in Section 3 how to better account for complexity in geological disposal systems.

\subsubsection{Metabolic Representation}

To complement the conventional engineering representation, geological disposal systems can also be represented-along with their interactions with natural systems-as open (self-modifying) systems [26]. That is, when parts of an engineering system interact with other systems of a complex nature, its complete description must be based on a perspective that captures that complexity. For instance, the fact that a repository interacts with natural processes makes the overall repository system complex. The key feature brought by the adoption of a complex systems representation is the ability to represent the system across different scales. Indeed, as we shall see in Section 3, the concept of scale does matter when characterizing geological disposal systems. A satisfactory approach to representing disposal systems must therefore be able to deal with multiple scales of analysis, across space, time, and functions.

Given that open self-modifying systems can be-and have been-successfully represented using a complex systems approach that considers their characteristics of non-linear relations and self-organization $[26,35,36]$, we argue that adopting such an approach to represent geologic disposal systems is possible and that it would improve the techno-scientific understanding and science-policy discussions about radioactive waste disposal issues. 


\section{Results}

As shown in Section 2, distinct representations can co-exist that refer to non-equivalent perceptions about what the system is [31]. Then, as models are a precondition for knowledge acquisition, adopting a given model — even conceptual — to represent a system implies an unavoidable loss on some of the characteristics of that system because all systems are a simplification of the nature of the system and its behavior. This is what makes all models suffer from some deficiencies and hence they can never be right [37]. For this reason, the question then is whether some models can be useful in addressing a given question or set of questions [38]. An integrated representation of disposal systems therefore would benefit from looking at, as much as possible, the relevant attributes that can be used to perceive and describe what nuclear disposal is and what it does. This requires shifting the representation from the engineering view to a metabolic view in order to describe disposal systems from a technically complete, integrated perspective. A metabolic view describes a system through various compartments, each responsible for a (set of) function(s) within the system, just like different organs provide metabolic functions to the human body. The functional compartments are hierarchically organized as a means to address complexity by describing the system across multiple scales. We thus obtain a set of attributes, hierarchically-organized by functions, for which we identify possible interrelations so that the metabolic behavior of the system is revealed [32].

In Section 3.1, we present the general integrated formalism for the metabolic representation of disposal systems based on a complete definition of its functions and scales. This integrated formalism is flexible in that it can be tailored to specific situations and formalized to support different types of integrated analyses at the back-end of the nuclear fuel cycle. We then provide in Section 3.2 an application of the formalism based on the example of the proposed geologic repository at Yucca Mountain in Nevada. Finally, in Section 3.3, we extend the integrated formalism to the issue of socio-technical interactions that impact geological disposal systems using two examples from the U.S. nuclear waste disposal program.

We remind the reader that this proposed formalism is conceptual and represents the possible organization of information-potentially, both quantitative and qualitative-for an encompassing approach to nuclear waste disposal systems. This proposed formalism is at an early stage of development; hence, we welcome feedback from the scientific and social communities working on these issues.

\subsection{General Integrated Formalism of Geological Disposal Systems}

The complexity of a system resides in the possibility to distinguish various subsystems that depend on the choices made by the observer as to how to interact with the system [31]. These subsystems correspond to the different possible scales at which the system is perceived. A system can be perceived either from the outside (external view) or from the inside (internal view), across spatial, temporal and functional scales. The system will behave differently, depending on the choice of the scales of the analysis.

The choice of scales can vary depending on the purpose of the analysis. Scales are defined through the boundary conditions and time horizons of the analysis. Once they are defined, they must be treated differently in the analysis because their corresponding formalizations are incommensurate, although all are necessary to describe the system as a whole [39]. We present in this section how disposal systems can be described across multiple scales of analysis, thus defining the proposed integrated formalism.

\subsubsection{Integration of Functional Scales}

Geological disposal systems can be understood by examining the hierarchical organization of their internal attributes that describe their different functions (or processes) across functional scales (or levels). (Throughout the paper, we use the term "functions" to refer to the description of "what the system does." Later in the paper we use the term "processes" to refer to the activation of functions in the evolution of disposal systems. Each function or process can be described across multiple (functional) 
scales that we call "levels." In contrast, we use the term "attributes" to refer to the description of "what the system is." As attributes and functions convey different semantic definitions in the formalism, we tried as much as possible to specify what we refer to. For instance, "waste forms" alone refers to the attribute simply describing this physical—more importantly, chemical—feature in the system, whereas "processes involving the waste forms" refer to the function in the disposal system's behavior. In some instances, however, attributes are defined by their functions as it is the case for "geological processes" and "exogenous processes." In our view, this relative overlap between functions and attributes does not affect the validity or usefulness of the formalism.) In this view, disposal systems (level $\mathrm{n}$ in Figure 1) are defined by means of three main attributes:

1. Waste materials describe the types, composition, associated level of radioactivity, properties and treatments in relation to the materials.

2. Repository design describes the functions and properties of the multiple barrier system. The engineered barriers-including the waste form, the waste package, and the structural barriers-are designed to delay the access of water to the waste package or the release of radionuclides from a breached canister. The geological barriers-including the surrounding backfill (or overpack) and the host rock-exploit the properties of the rock and hydrologic system to extend the migration time required by the radionuclides to reach the biosphere.

3. Site characteristics describe the natural processes that directly affect the geological conditions of the repository through the geological processes-including geophysics, geochemistry, and hydrology — and indirectly through exogenous processes—including changes in the biosphere, seismic activity, volcanism, climate change, erosion, glaciation, and human intrusion.

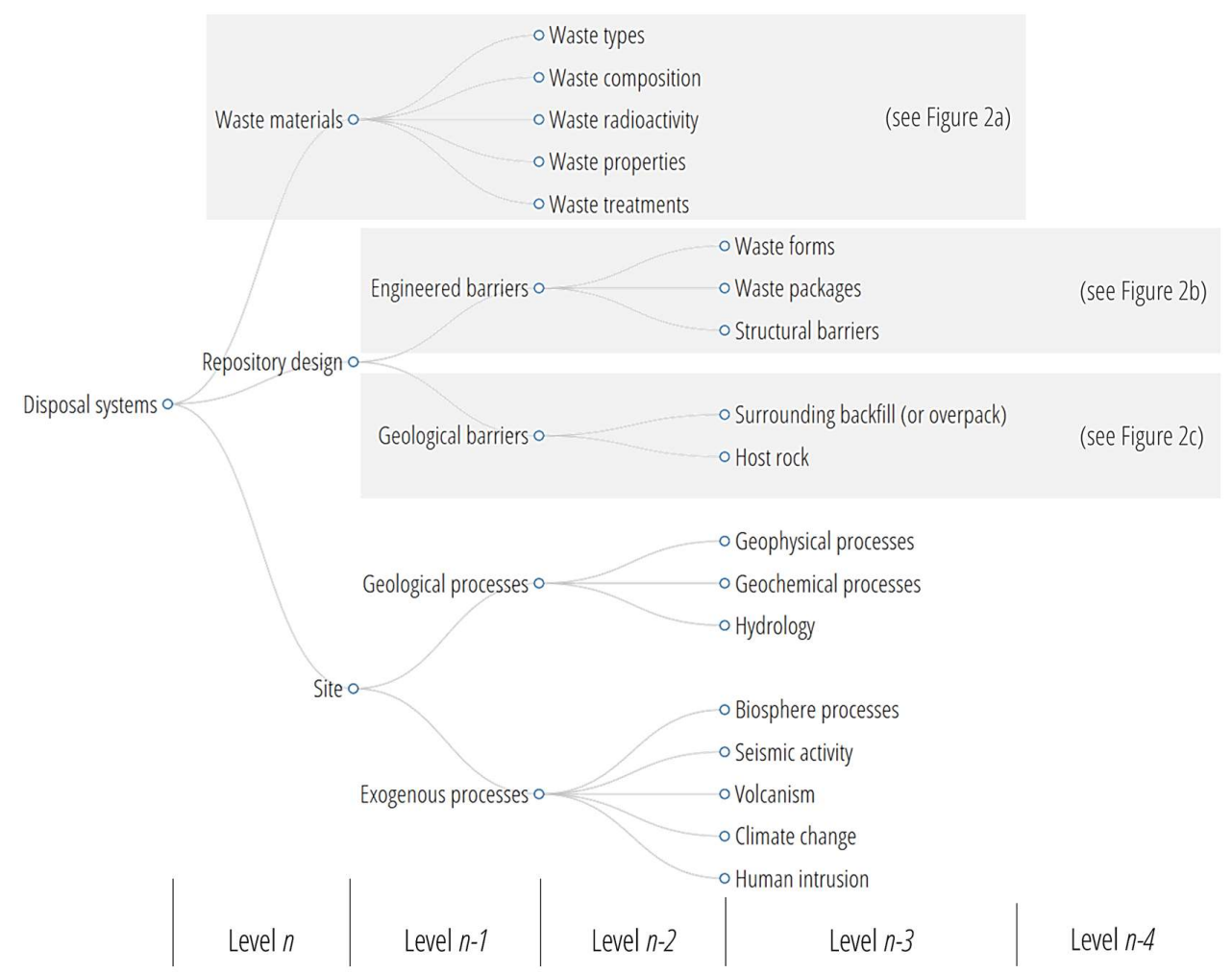

Figure 1. Inside view of nuclear waste geological disposal systems. Higher-level attributes shown through level $n$-3 (except for attributes of the "Waste materials" category shown through level $n-2$ ) The lower-level attributes through level $n-4$ are provided in Figure 2. Sources: [1,40-42]. An interactive version of this figure is available here: https://francoisdm.github.io/attributes/. 
a.

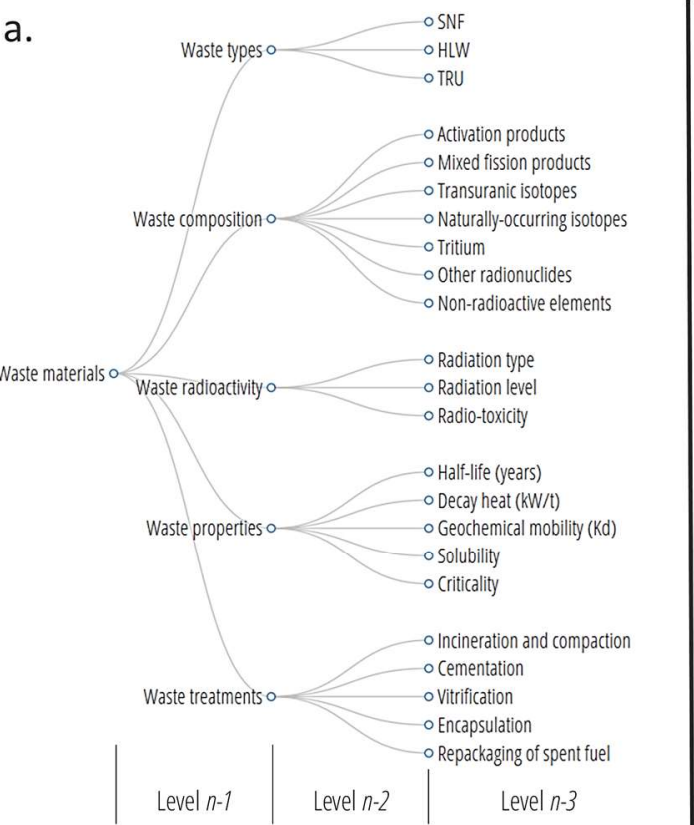

b.

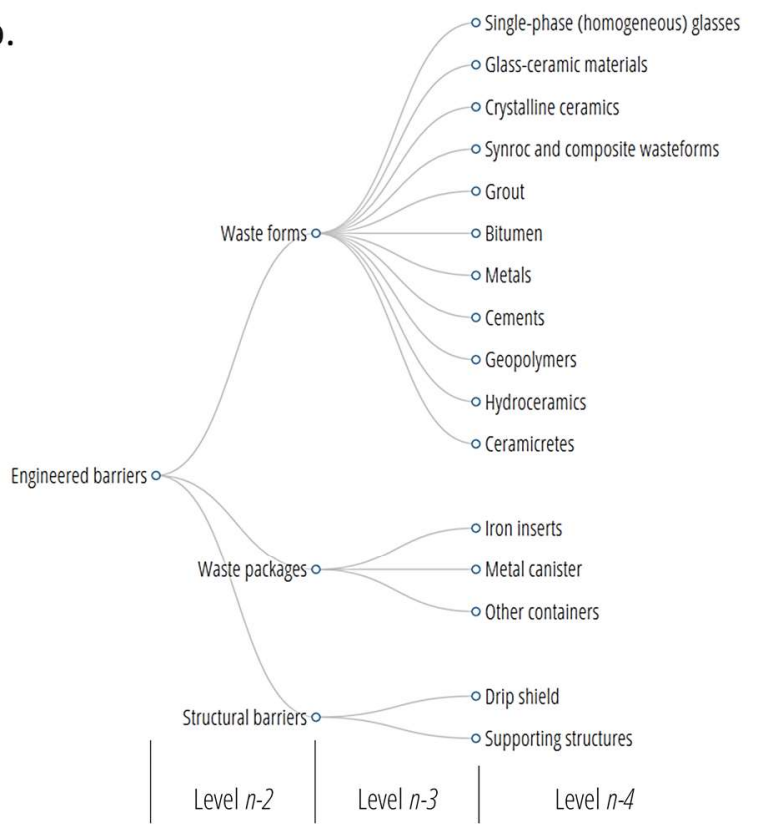

c.

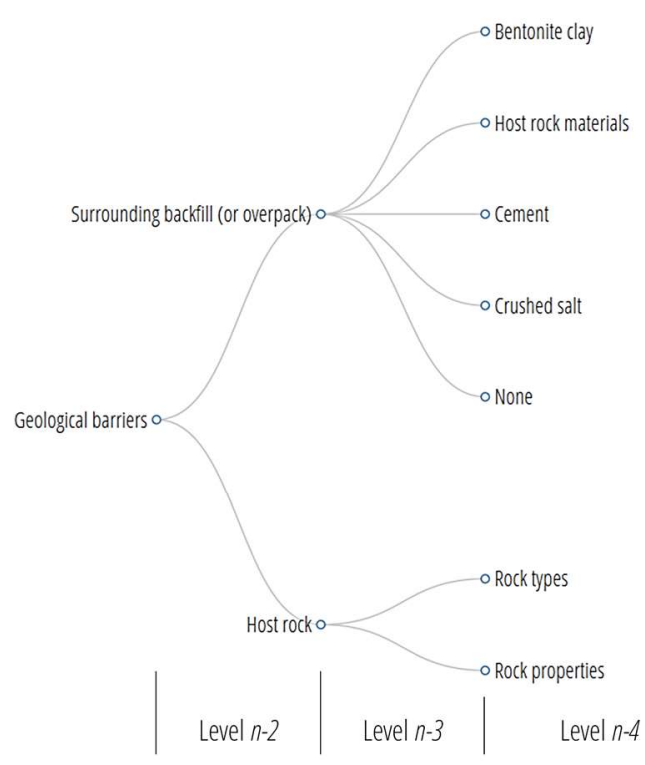

Figure 2. Lower-level attributes of disposal systems for the categories "Waste materials" (level $n$-1) through level $n$-3 (a), "Engineered barriers" (level $n$-2) through level $n-4$ (b), and "Geological barriers" (level $n-2$ ) through level $n-4$ (c). Note: The attribute "host rock" (Figure $2 \mathrm{c}$ ) refers here to the geologic environment or setting, which captures the rock type, properties and function in the geologic repository. We use the term "host rock" in place of geological environment to avoid the confusion with geological processes that happen as part of the "Site" main category (Figure 1). Sources: [1,40-42]. An interactive version of this figure is available here: https://francoisdm.github.io/attributes/. 
The three main attributes-Waste-Repository-Site-correspond to the highest level at which disposal systems can be described from within (level n-1). These attributes are the essential parts of geological disposal systems and thus define the main levels of analysis in a technically complete, metabolic representation of those systems. Waste materials and Repository design relate to the very nature of the geological disposal systems, whereas Site refers to how those systems interact with the environment through the lithosphere and the biosphere.

Adopting these main attributes, we present in Figure 2, a set of the 71 attributes used to describe disposal systems across scales, down to level $n-4$. The inside view corresponds to the description of what happens within the disposal systems. Each individual attribute conveys a key piece of information about the system (the parts) that, at the same time, depends on the rest of the information system (the whole). That is, internal attributes of disposal systems may express features that can have an effect at higher levels but are only possible to observe looking at the parts. Conversely, features observed at a higher level may not be directly seen at lower levels, as illustrated in Section 3.2.2. These complex relations between parts and whole are essential to provide a meaningful characterization of a complex system. The multi-scale, functional representation provided in this section seeks to respond to the call for the integration of the back-end of the nuclear fuel cycle $[10,11]$, focusing here on the problem of geological disposal.

We further detail in Figure 2 the lower level attributes that could not be shown on Figure 1 for reason of space.

The attributes considered in the integrated formalism to represent disposal systems (level $n$ ) are summarized in Table 1 looking at the high-level hierarchical sequence (levels $n-1 / n-2$ ).

Table 1. List of attributes describing nuclear waste disposal systems (level $n$ ) through levels $n-1$ and n-2. Sources: [1,40-42].

\begin{tabular}{|c|c|c|}
\hline Level $n$-1 Attributes & Level $n$-2 Attributes & Abbreviations Used \\
\hline \multirow{5}{*}{ Waste materials (25) ${ }^{(a)}$} & Waste types (3) & WTYPE \\
\hline & Waste composition (7) ${ }^{(b)}$ & WCOMP \\
\hline & Waste radioactivity (3) (c) & WRAD \\
\hline & Waste properties (5) ${ }^{(d)}$ & WPROP \\
\hline & Waste treatments (5) & WTREAT \\
\hline \multirow{2}{*}{ Repository design (30) } & Engineered barriers (19) & ENG-B \\
\hline & Geological barriers (9) & GEO-B \\
\hline \multirow{2}{*}{ Site (10) } & Geological processes (3) & GEO-P \\
\hline & Exogenous processes (5) & EXO-P \\
\hline
\end{tabular}

Notes: (a) When applicable, indicates the number of attributes considered in the analysis at the lowest level of each sub-category. ${ }^{(b)}$ We included non-radioactive elements as part of the waste composition (Figure 2a) given these attributes contribute also to the risk. (c) The composition drives the radioactivity, but it is important to keep track of radiation-type, radiation-level, and radio-toxicity. Although these are derived parameters, each captures a different part of the risk associated with the composition of the waste. ${ }^{(d)}$ The specific activity is directly related to the half-life. The shorter the half-life, the higher the specific activity. Hence, when we speak of low levels of activity, this could mean that we have radionuclides with very long half-lives. For this reason, we kept half-life as a separate waste property from waste radioactivity (Figure 2a).

The inside view presented in this section as part of the general integrated formalism is conceptual. That is, the chosen attributes and their hierarchical, functional relations are only based on the logic of the system; hence they do not convey quantitative information per se (we provide in Section 3.2 an example of relations across functions based on transfer of quantitative information). Moreover, our definition of disposal systems in the inside view refers only to its technical attributes considering the societal context as external boundaries to the systems (see Section 3.3). 
Moreover, as the general formalism only provides attributes down to level $n-4$, clearly, each one of these low-level attributes could be further expanded to differentiate between the different possible instances of disposal systems. For instance, "rock types" (level $n-4$ in Figure 2c) could be divided into "strong rocks with low porosity and few fractures" (e.g., basalt, gneiss, granite, granodiorite, migmatite) and "relatively weak mud-rocks or clays" (e.g., argilite (clay), sedimentary rock, shale, tuff, rock salt); whereas "Metal canisters" (level $n-4$ in Figure 2b) would include various types of metals such as steel, copper, advanced corrosion-resistant alloys, stainless steel, iron, all showing different properties and evolving mechanisms in deep, mined geological repositories.

Therefore, rather than exhaustivity, the general integrated formalism, as presented in this section, provides a technically complete, high-level functional description of disposal systems by identifying their main attributes that cover all the processes involved in the deep geological disposal of highly-radioactive waste, except for surface storage and transportation (see Section 3.3). Using the terminology from theoretical ecology [31], the metabolic representation presented here is able to describe all the main functional types (processes) involved in deep geological disposal, although it does not cover all the possible instances (a unique set of attributes) of all possible disposal systems.

Despite those limits, this integrated formalism can encompass the different perceptions of disposal systems from the various concerned techno-scientific communities-such as engineers, geologists, geochemists, hydrologists, and material scientists-each focusing on different aspects of the systems. Such an integrated formalism can be useful for analysts to identify more conveniently the boundaries of their studies or models by knowing which attributes are included and which are not. Moreover, the hierarchical organization of attributes in this metabolic formalism allows the analysts and non-specialists to better understand the complexity of disposal systems. This is achieved by collapsing non-relevant information while, at the same time, being able to reach a greater level of detail depending on the purpose of the analysis. More broadly, this approach can be useful to organize information because it follows an ontological approach to knowledge organization [43] that can help to better represent complex disposal systems. For instance, it can be particularly useful to track which processes are captured by the models and how these processes are activated in total system performance assessments of geologic repositories-as shown in Section 3.2.

\subsubsection{Integration of Spatial and Temporal Scales}

The various processes involving nuclear waste, the repository, and the site in disposal systems are subject to changes as a function of time. Yet, these processes operate at different timescales. For instance, the properties of the waste materials evolve more rapidly during the first 1000 years when the waste are still thermally active-in the case of a "hot" repository like the proposed Yucca Mountain repository, in contrast to a "cold" repository where the waste do not have a thermal pulse [44] —-thus affecting the engineered barriers and the near-field of the geologic repository. Similarly, geochemical processes will not be activated for at least 10,000 years, when the waste package is degraded so radionuclides can reach the geological medium. Exogenous processes, such as changes in the biosphere, seismic activity, volcanism, glaciation, and human intrusion, are such unlikely events that they are generally not considered to happen for at least 20,000 years. As we can see, the analysis of disposal systems requires one to consider several timescales to describe the several processes at play. Yet, any choice of a specific timescale will not allow one to account for processes that occur at a different timescale. For instance, a timescale of 1000 years is adequate for studying the effects of thermal output from the waste materials on the near-field of the geological medium, whereas the long-term geological and exogenous processes require a time horizon much longer than 1000 years.

Considered from an analytical perspective, the co-existence of distinct timescales, each characterizing a sub-set of processes relevant in disposal systems explains how time can be subject to contrasting perceptions for which there exist non-equivalent possible representations of disposal systems in time. We present in Table 2, the four general timescales that can be considered when discussing how disposal systems evolve with time. The choice of timescale in the analysis depends on which one(s) of the 
processes are considered. Therefore, the timescale associated with the processes under consideration sets the analytical time required for their analysis-although compliance period may be shorter (see Section 3.3.3). Table 2 provides a mapping between time and the main processes identified in geological disposal systems.

Table 2. The various timescales of nuclear waste disposal systems. Sources: [42,45].

\begin{tabular}{|c|c|c|}
\hline Period & Timescale (Order of Magnitude) & Processes Involved \\
\hline Operational period & $\sim 10^{2}$ years before closure & $\begin{array}{l}\text { Period of repository construction, waste } \\
\text { emplacement, and repository closure. } \\
\text { Radiation field dominated by beta decay }(\beta-) \\
\text { and gamma radiation }(\gamma) \text {. }\end{array}$ \\
\hline Thermal period & $\sim 10^{3}$ years after closure & $\begin{array}{l}\text { Period of waste form degradation dominated } \\
\text { by decay heat from the waste, radio-chemical } \\
\text { processes inside the waste package and the } \\
\text { related coupled thermal, hydrological, and } \\
\text { mechanical processes in the near-field of the } \\
\text { geological medium. Radiation field dominated } \\
\text { by alpha decay }(\alpha) \text {. }\end{array}$ \\
\hline $\begin{array}{l}\text { Engineered barriers } \\
\text { period }\end{array}$ & $\sim 10^{4}$ years after closure & $\begin{array}{l}\text { Period of waste package degradation } \\
\text { dominated by geochemical and hydrological } \\
\text { processes at the interface with the geological } \\
\text { medium. Radiation field dominated by alpha } \\
\text { decay }(\alpha) \text {. }\end{array}$ \\
\hline Geological period & $\sim 10^{5}$ years after closure & $\begin{array}{l}\text { Period of radionuclides transport to the } \\
\text { biosphere dominated by geological and } \\
\text { exogenous processes. Radiation field } \\
\text { dominated by alpha decay }(\alpha) \text {. }\end{array}$ \\
\hline
\end{tabular}

As we shall see in Section 3.2 in the context of the proposed Yucca Mountain repository, timescales and functional scales (levels) are correlated because processes are expected to be activated differently depending on the chosen timescale of analysis. Moreover, temporal scales of the disposal systems are also correlated with spatial scales. That is, as time passes, the disposal system is expected to expand spatially as illustrated by the scale of the processes activated at different time periods during the evolution of the system. Under nominal conditions, that is, in the absence of an external event, the spatial expansion of disposal systems follows the expected path of migration of the radionuclides through the various barriers of the system in time. Radionuclide migration will require the activation of coupled processes involving (1) the waste form and the engineered barriers (few meters) during the operational period; (2) the waste form, engineered barriers and near-field of the geological system (tens of meters) during the thermal period; (3) the engineered barriers, near-field and the lithosphere (few kilometers) during the engineered barriers period; and finally (4) the lithosphere and the biosphere (tens of kilometers) during the geological period. Therefore, given their correlation with the timescales, spatial scales are implicitly integrated in the formalism.

\subsection{Application of the Integrated Formalism to the Yucca Mountain Repository}

Here we apply the integrated formalism presented in the previous section to the proposed Yucca Mountain repository in Nevada. This example intends to assess the level of complexity considered in the total system performance assessment (TSPA) of the safety analysis report (SAR) supporting the license application (LA) that was reviewed by the U.S. Nuclear Regulatory Commission [46,47]. The TSPA is a modelling approach to the repository system based on probabilistic calculations used to demonstrate the compliance of the Yucca Mountain repository [30]. While probabilistic calculations are commonly used in geologic repository design [28,29], the TSPA approach is specific to the United States in that its conceptual structure relies on a mathematical framework connecting models to represent 
the overall evolution of the disposal system [48]. The TSPA-LA of the Yucca Mountain repository is organized around eight model components and 23 model sub-components (Table 3). In total, the TSPA-LA accounts for about 300 sub-models [30]. Yet, as discussed in Section 2.2.1, the TSPA-LA does not inform well about the level of complexity considered in modelling the repository system. This affects the understanding of whether the TSPA-LA adequately connects coupled processes together and, as a result, how the results of the TSPA-LA can be interpreted by reviewers, the public and the analysts themselves.

Table 3. List of model components (8) and sub-components (23) used in the total system performance assessment supporting the license application (TSPA-LA) of the Yucca Mountain repository. Acronyms are provided in Appendix B. Source: Table 6-1 of [46].

\begin{tabular}{|c|c|c|}
\hline Model Components & Abbreviations Used & Model Sub-Components \\
\hline Unsaturated zone (UZ) flow & UZ-F & $\begin{array}{l}\text { Site-scale UZ flow } \\
\text { Infiltration analysis } \\
\text { Climate analysis } \\
\text { Drift seepage } \\
\text { Drift wall condensation }\end{array}$ \\
\hline $\begin{array}{l}\text { Engineered barrier system } \\
\text { (EBS) environment }\end{array}$ & EBS-E & $\begin{array}{l}\text { EBS thermal-hydrologic environment } \\
\text { EBS chemical environment }\end{array}$ \\
\hline $\begin{array}{l}\text { Waste package (WP) and } \\
\text { drip shield (DS) degradation }\end{array}$ & WP\&DS-D & $\begin{array}{l}\text { WP and DS degradation (WAPDEG) } \\
\text { Localized corrosion on the WP outer surface }\end{array}$ \\
\hline $\begin{array}{l}\text { Waste form (WF) } \\
\text { degradation and } \\
\text { mobilization }\end{array}$ & WF-D\&M & $\begin{array}{l}\text { Radionuclide inventory } \\
\text { In-package chemistry } \\
\text { Cladding degradation } \\
\text { Commercial SNF, defense SNF, HLW degradation } \\
\text { Dissolved radionuclide concentration limits } \\
\text { WF \& EBS colloids }\end{array}$ \\
\hline EBS flow and transport & EBS-F\&T & $\begin{array}{l}\text { EBS flow } \\
\text { EBS transport }\end{array}$ \\
\hline Unsaturated zone transport & UZ-T & UZ transport \\
\hline SZ flow and transport & SZ-F\&T & $\begin{array}{l}\text { 3-D SZ flow and transport } \\
\text { 1-D SZ flow and transport }\end{array}$ \\
\hline Biosphere & Biosphere & $\begin{array}{l}\text { Nominal biosphere dose conversion factors } \\
\text { (BDCFs) } \\
\text { Groundwater protection conversion factors } \\
\text { Disruptive events BDCFs }\end{array}$ \\
\hline
\end{tabular}

\subsubsection{Interfacing Models and Processes}

Looking at the list of model components shown in Table 3, it is difficult to understand which one of the processes are involved in the repository evolution under nominal conditions. This is because the sub-models do not follow a hierarchical structure, apart from being organized under eight model components. Unlike the attributes of the integrated formalism that explicitly refer each to one process of the disposal system, each model can involve several processes, making it difficult to have an overall understanding of how the non-linear relationships between coupled processes are computed in the TSPA-LA.

We present in Figure 3 the correspondence between the model sub-components and the attributes of the disposal system. This interface provides an example of how to connect the engineering representation-through the model components shown in Table 3-to the integrated formalism of disposal systems - through the attributes presented in Figures 2 and 3. That is, by connecting the engineering representation to the integrated formalism, we build a metabolic representation of the Yucca Mountain repository, based on the perspective of the analysts who developed the TSPA-LA. 


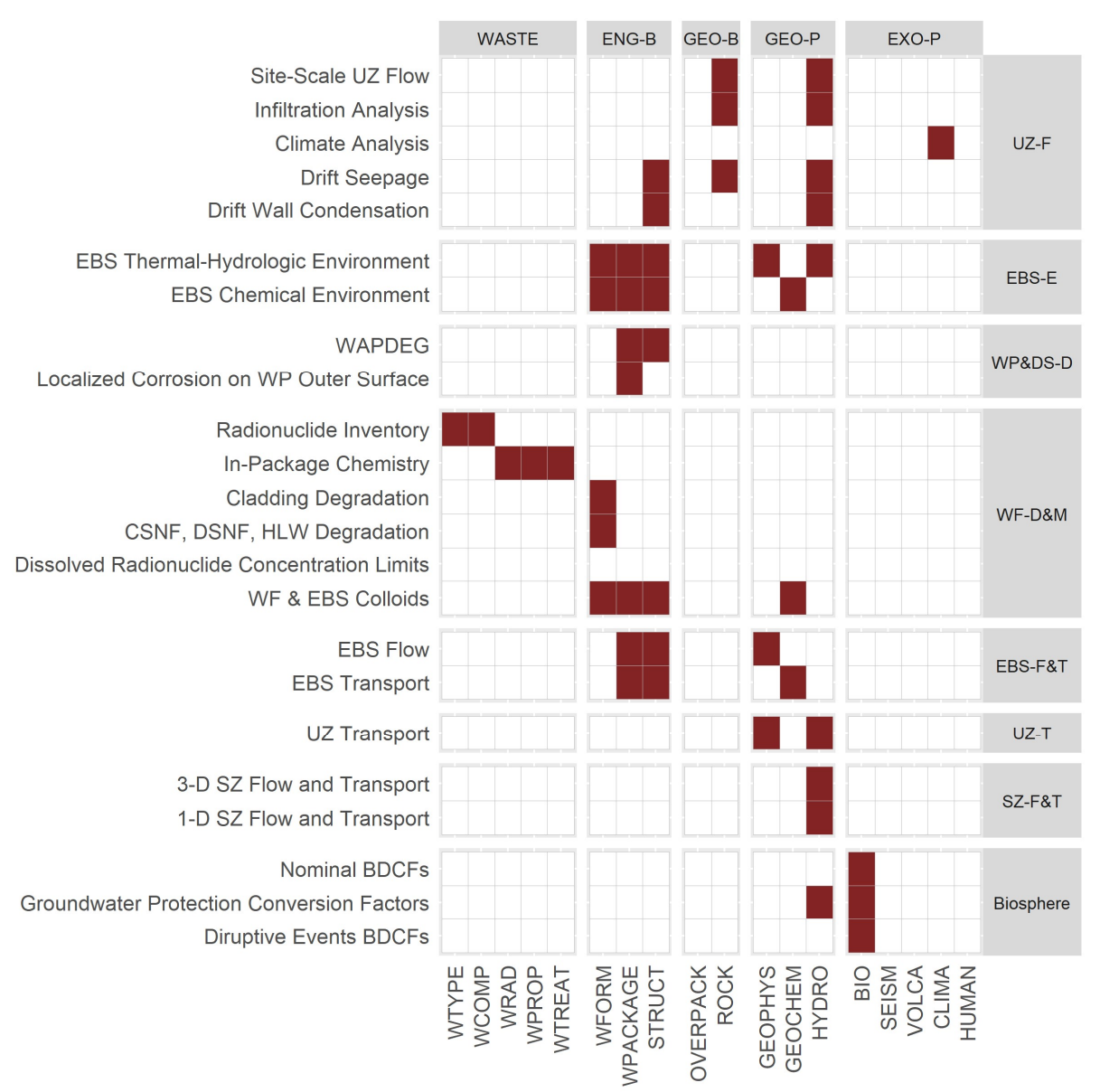

Figure 3. Correspondence between the attributes from the metabolic representation of disposal systems ( $\mathrm{X}$ axis) and the model sub-components used in the total system performance assessment supporting the license application (TSPA-LA) of the Yucca Mountain repository ( $Y$ axis). Acronyms are provided in Appendix B.

\subsubsection{Revealing the Complexity}

We can now assess the level of complexity considered in the TSPA-LA by looking at the correlations between the attributes describing the various processes at play. To show this complexity, we first computed the model correlations by analyzing the information transfer between the model components and sub-components of the TSPA-LA nominal scenario class [46], as shown in Figure 4.

The nominal scenario class of the TSPA-LA corresponds to the expected evolution of the repository in the absence of events such as the early failure of a waste package or a drip shield, seismic activity, volcanism or human intrusion. We based our analysis on the nominal scenario class because it essentially has the same conceptual structure and computational organization as the other scenarios considered in the TSPA-LA, except that it does not include 'events' [48].

By using the models/attributes interface matrix (Figure 3) and the models correlation matrix (Figure 4), we were then able to assess the complex relations that exist between the processes of the repository system using the integrated formalism. Figure 5 presents a visualization of the level of complexity introduced in the TSPA-LA of the Yucca Mountain repository. As such, it translates the level of understanding from the analysts about how the various processes are inter-connected. In other words, given that the future evolution of a repository system cannot be known with certainty, it corresponds to the best available understanding of the complexity of the system; thus, it acts as the image of the actual system from the view of the analysts. 


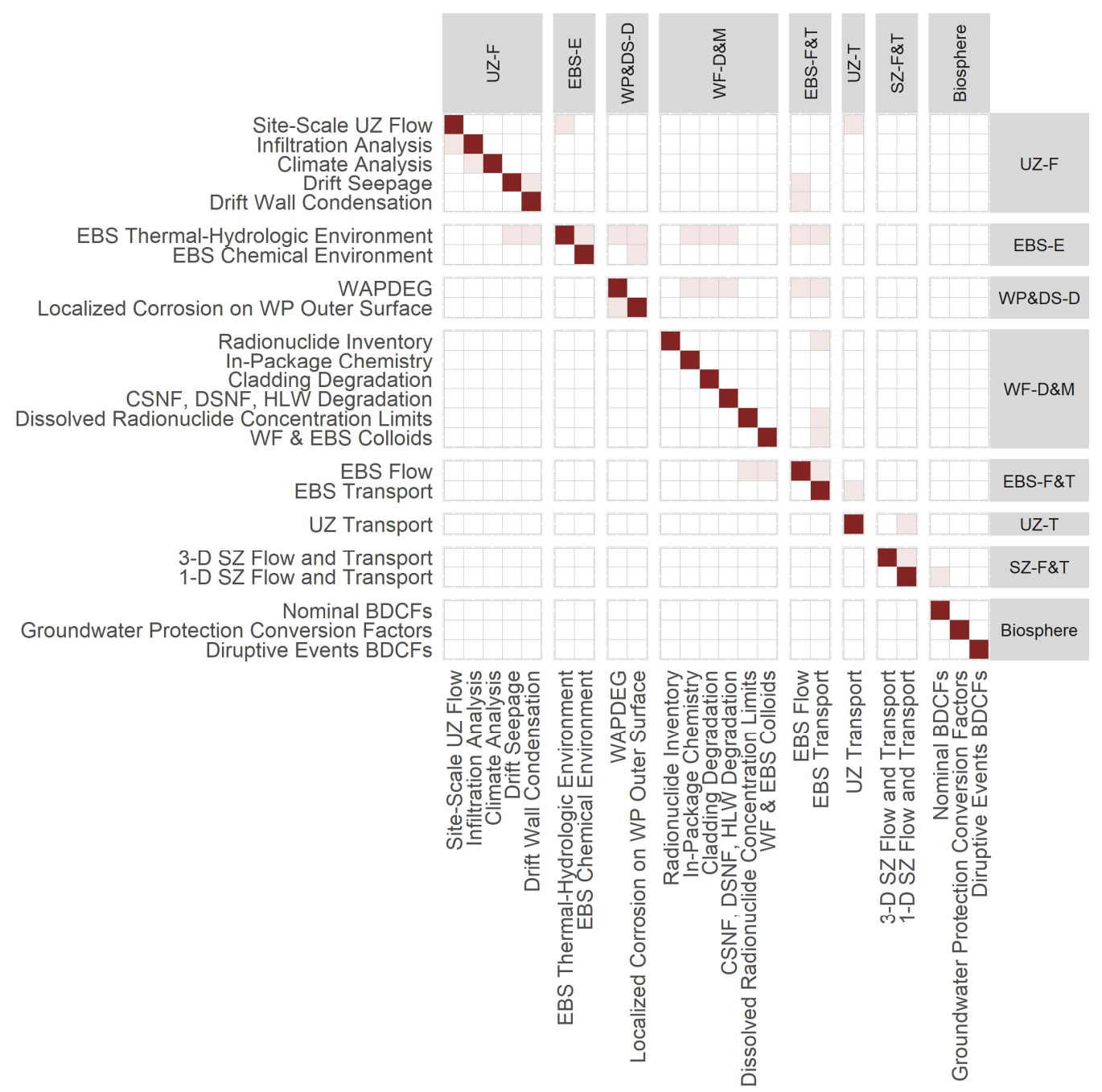

Figure 4. Correlations between model sub-components used in the total system performance assessment supporting the license application (TSPA-LA) of the Yucca Mountain repository. Correlations between outputs from model sub-components ( $\mathrm{Y}$ axis) and inputs to model sub-components ( $\mathrm{X}$ axis) are shown for the nominal scenario class. Light red squares indicate correlation between different model sub-components, whereas strong red squares indicate correlation between same model sub-components. Acronyms are provided in Appendix B. Source: after Figure 6.1.4-1 of [46].

Figure 5 reveals the strong coupling between the high-level processes involved throughout the evolution of the geologic repository system. As we can see from the figure, the attribute "overpack" is not involved. This is because the Yucca Mountain repository design does not include the use of a backfill material. Moreover, as the figure presents the repository under nominal conditions, it does not include exogenous processes of changes in the biosphere, seismic activity, volcanism and human intrusion. Only a climate analysis is included as part of the unsaturated zone flow model component (UZ-F in Table 3). (In the TSPA of the Yucca Mountain repository [46,47], climate change was considered to be fundamentally different than volcanism or seismicity. Climate change was considered to occur with a probability of 1 . Therefore, the time and amount of change were introduced as uncertain input parameters in the analysis, but the process was included in all scenarios. Volcanism and seismicity, however, were treated as aleatory uncertainties and included in separate scenarios conditional on those exogenous events.) 


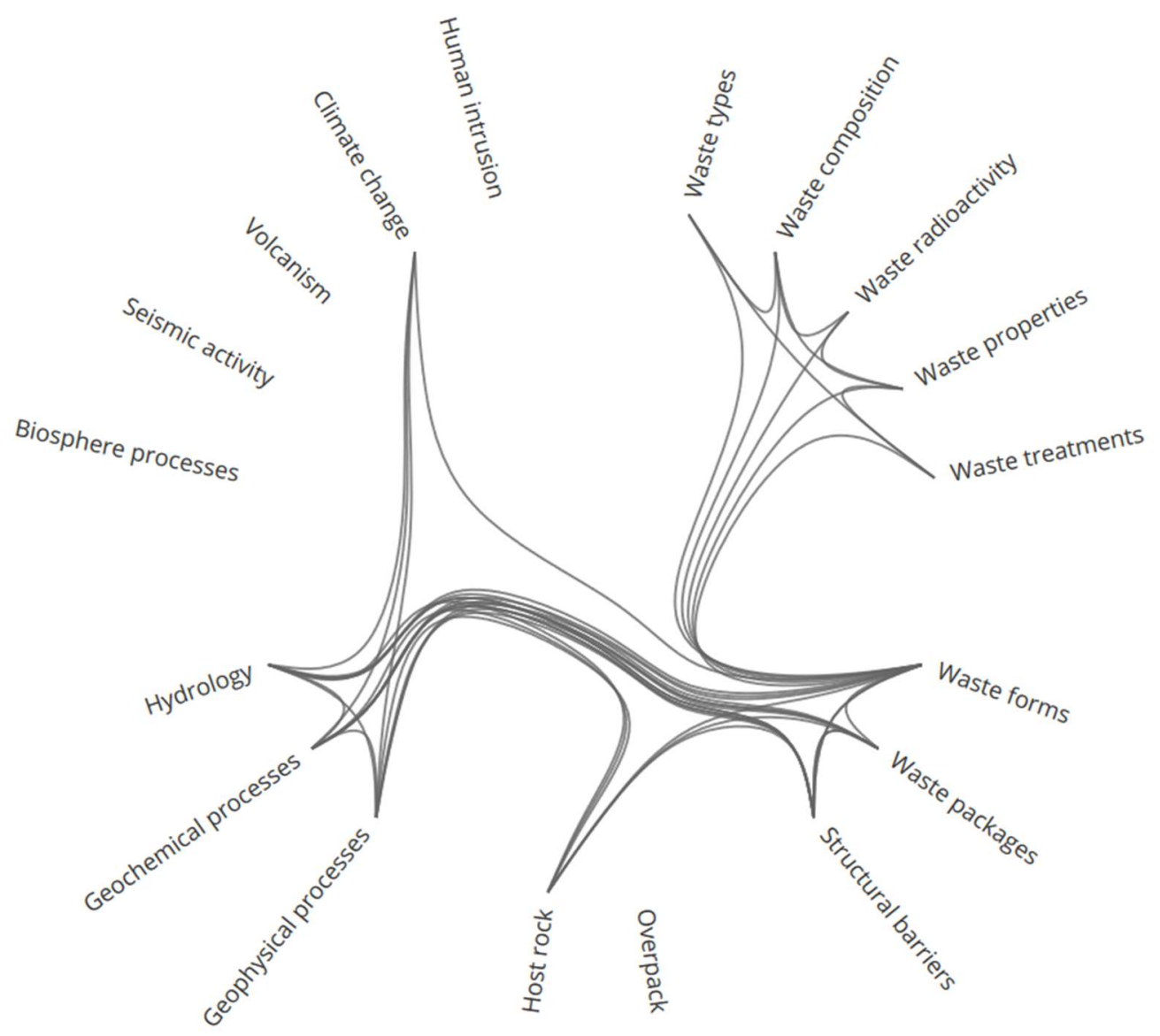

Figure 5. Complex relations between the processes involved in the Yucca Mountain repository as computed in the TSPA-LA nominal scenario class.

While this figure helps one to understand the non-linear evolution of the repository, it shows the complex relations all at once. Yet, not all processes will be activated at the same time in a repository. Therefore, to better account for the complexity of the Yucca Mountain repository system, we must look at the coupled processes through different timescales, as shown in the next section.

Note, this analysis is based on the complex relations that exist between model sub-components. It does not account for the complex relations that may exist within each sub-model used in the TSPA-LA, within each attribute. Rather, this analysis provides a high-level approach to visualizing the complexity across processes of the repository system. Therefore, the complex relations internal to each attribute shown in Figure 5 are considered implicit.

\subsubsection{Cutting through the Complexity}

As explained in the previous section, complexity of the repository system can be better assessed by looking at the processes against the different timescales presented in Table 2. "Cutting through the complexity" means to be able to assess complex relations across spatial scales (through processes) and timescales (through their various periods). Figure 6 presents the complex relations between processes for each one of the four time periods-operational, thermal, engineered barriers, and geological (Table 2).

Referring to the technical complexity of disposal systems discussed in Section 2.1, Figure 6 shows the different patterns of the complex relations that occur at the different periods during the evolution of the repository under nominal conditions. For instance, during the operational period (Figure 6a), complex relations in the geological repository are dominated by the mutual interactions between 
waste materials, the engineered barriers (waste forms and waste packages), and geological processes (hydrology and geophysical processes), whereas the system remains under the present-day climate.

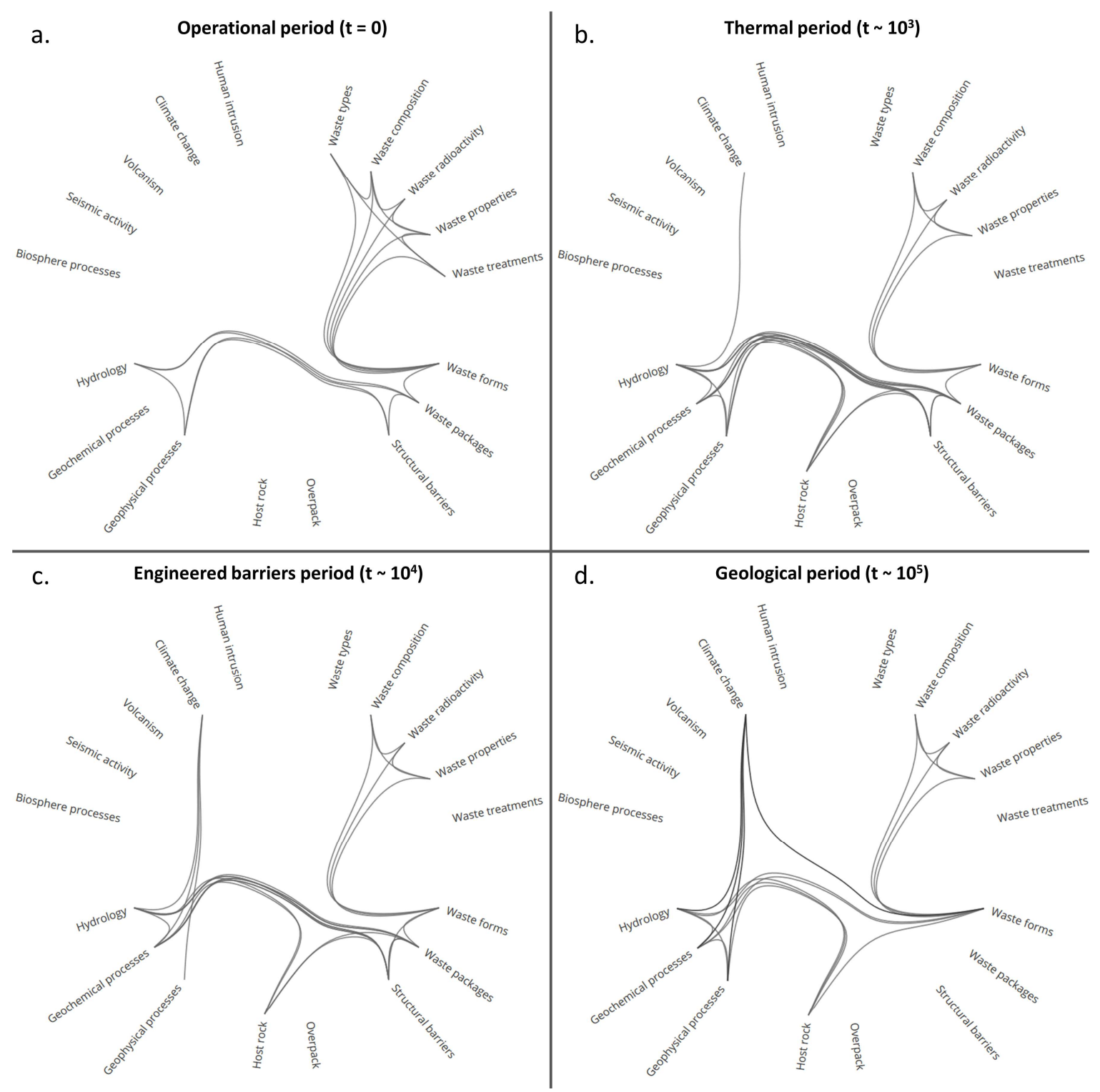

Figure 6. Complex relations between the processes involved in the Yucca Mountain repository as computed in the TSPA-LA nominal scenario class during the operational period (a), the thermal period (b), the engineered barriers period (c), and the geological period (d). In (a), $t=0$ corresponds to the repository closure, that is, to the end of operational period.

Then, during the thermal period after closure (Figure $6 \mathrm{~b}$ ), the repository experiences many more coupled processes, involving the waste materials, the engineered and geological barriers, and the geological processes; whereas, change to a monsoon climate will also affect the hydrology of the system ([46], Section 6). As Figure 6 shows, the thermal period is when non-linearity most affects the evolution of the repository system because all the geological processes (hydrologic, geochemical and geophysical), which are more difficult to model and predict, are coupled with both the engineered and geological barriers. These are the so-called thermal, hydrologic, mechanical, and chemical (THMC) processes that are known to drive non-linearity in sub-surface systems, including geological repositories [49]. 
Once the thermal period is over, after peak thermal effects are reached at about $10^{3}$ years after closure (Figure 2.3.5-33 of [47]), the repository returns to isothermal conditions at around $10^{4}$ years when the repository enters into the engineered barriers period (Figure 6c). During this period, under nominal conditions, the repository response is mainly driven by the hydrologic and geochemical processes that interact with the engineered and geological barriers. Moreover, the system will then be susceptible to perturbations by hydrologic, geophysical, and geochemical effects caused by changes in climate ([46], Section 6).

Finally, after the engineered barriers have been degraded enough to release radionuclides that then migrate into the near surface environment and biosphere, the repository enters the geological period (Figure 6d). During this period, complex interactions no longer involve the waste packages and structural barriers assumed to have failed but, rather, geological processes that interact directly with the waste forms and the geological barriers. Moreover, in the post-10,000-year climate, e.g., possible interglacial, pluvial periods will further cause changes in the infiltration rates that affect the hydrologic, geophysical, and geochemical conditions.

The visualization of the complex relations in a repository system, as shown in Figure 6, also allows one to identify the key parameters. For instance, in the nominal scenario class of the TSPA-LA, a peak dose-the maximum mean value that is well below regulatory limits-is expected to occur around 720,000 years after closure, when corrosion of the waste package allows the release and migration of radionuclides to the lithosphere and then to the biosphere through transport in the unsaturated and saturated zones [47]. That is, if the repository evolves as expected under those nominal conditions, radionuclides will not be released to the biosphere in sufficient quantities to represent a threat to future generations living in the area. Yet, the total system results are sensitive to uncertain input parameters. For instance, in the nominal scenario class, the "temperature dependent slope term of Alloy 22 general corrosion rate (K)" (WDGCA22 in [48], Appendix B) as well as the "deviation from median yield strength range for outer waste package lid (dimensionless)" (WDZOLID in [48], Appendix B) are driving the uncertainty in the analysis (Table 2.4-12 of [47]).

Given that these two parameters pertain both to the "localized corrosion on the WP outer surface" model sub-component, they belong to the "waste packages" attribute of the integrated formalism (see Figure 3 for models/attributes correspondences). Yet, as Figure 6 shows, the waste package is an important barrier in the early evolution of the Yucca Mountain repository system. The waste package is involved in the first three periods-operational, thermal and engineered barriers. This illustrates why the waste package failure is the most sensitive process in the TSPA-LA during the evolution of the repository system under nominal conditions. This means that the uncertainty quantification on these two parameters is key to the overall system because they are highly coupled with other processes.

\subsection{Extension of the General Integrated Formalism to Societal Constraints}

So far in this paper, we have presented a general integrated formalism based on a technical description of geological disposal systems (Section 3.1) and applied this formalism to the proposed Yucca Mountain repository (Section 3.2). What we have not considered, however, are the various societal dimensions also affecting disposal systems. As we shall show in this section, disposal systems do not "work" in isolation from the societal constraints. For instance, the proposed Yucca Mountain repository-and its associated performance assessment—is the result of a history of decisions made at the regulatory, legal, operational, and social levels. Thus, disposal systems must respond to societal constraints that act as external boundaries to the disposal strategy. Disposal systems are embedded-and mainly the product of-a broad network of decisions that occur at different times. For this reason, an additional dimension in the proposed integrated formalism consists of connecting the technical description of the disposal systems to social constraints.

In this section, we describe societal constraints to disposal systems (Section 3.3.1). We then propose an extension of the general integrated formalism. This extension aims to represent the societal constraints using a metabolic approach similar to the one used for the technical representation 
(Section 3.3.2). Lastly, we present two examples of socio-technical interactions impacting disposal systems in the context of the U.S. program (Section 3.3.3). These examples reveal the challenges in integrating the technical and social dimensions of geological disposal systems into a single formalism.

\subsubsection{Societal Constraints on Geological Disposal Systems}

Societal constraints fall into three main categories: regulatory compliance, legal requirements, and social acceptance. However, these categories themselves are affected by many cultural, political, economic, and social factors that describe the complex social context. In addition to the technical complexity presented in Section 2.1, the definition and representation of disposal systems are therefore affected by social complexity. Social complexity refers to the various interdependences between the societal constraints. These constraints will not affect directly the geologic performance of the repository, but will make a difference to the decisions made at the level of the national nuclear fuel cycle. Social complexity has implications on the definition of nuclear waste disposal systems, but those implications occur outside of these systems. Here, we provide some examples of socially complex relations that affect disposal systems:

- At the socio-economic and political levels, choices made about nuclear energy technologies in relation to energy policy directly affect the nuclear fuel cycle, which ultimately drive the technical needs at the back-end of the fuel cycle. In turn, decisions made about disposal strategies affect the energy policy discussions. Nuclear energy systems and nuclear waste disposal systems are therefore connected through socio-economic and political drivers.

- At the regulatory level, the safety provided by the multiple-barrier containment system of the geological repository is assessed based on quantitative information and, in the approach of a "safety case", also on qualitative arguments [50]. Although the quantitative assessment of safety is not the only basis for a licensing decision, in practice, regulatory records show a widespread reliance on quantification [51]. This quantitative approach to safety assessment is used to address the problem of the role and use of expertise in the decision-making process $[52,53]$. Multi-criteria decision analysis can also be used in nuclear waste management [13]. But there remains the problem of how to weight non-equivalent criteria so as to reach a decision $[54,55]$. In the U.S., for instance, the quantitative safety assessment of the Yucca Mountain repository is required to provide a probabilistic estimate of the dose received by a person at a specific time and location [56]. But, by using models that provide a quantitative estimate of anticipated dose to the public, the regulatory framework seems to assume that there can be a quantitative description of known exposure pathways. Yet, these pathways are impossible to predict far into the future given the high uncertainties-and unavoidable lack of knowledge of conditions in the far future. Regulators may be fully aware of the impossibility of projecting future human actions and natural processes. But the attempt to quantify the long-term performance of disposal systems, in the face of high uncertainties, has been at the center of public skepticism and controversy over the determination of whether a site is "safe" or not [57].

\subsubsection{Outside View of Geological Disposal Systems}

As presented in Section 3.1 and illustrated in Section 3.2, the complex relations between the processes involved inside the geological disposal system can be characterized using a metabolic representation. Similarly, geological disposal systems can be represented from the outside as part of their complex societal context. In this context, the various socio-economic sectors refer to the different functions of society, such as production, services, and institutions [58]. In the societal metabolism perspective [59], disposal systems (level $n$ in Figure 7) are represented as embedded within the nuclear power system (level $n+1$ ) that interacts itself with the other compartments of society (levels $n+$ $2 / n+7)$. Yet, a key aspect of disposal systems is that radioactive materials requiring disposal also come from other waste streams, namely from military, research and medical applications of nuclear 
processes (level $n+5)$. For this reason, radioactive materials are not embedded within a single societal compartment, unlike the products of other socio-economic functions such as food, energy, and services. Moreover, this paper focuses on highly-radioactive materials requiring deep geological disposal-mainly SNF and HLW. Therefore, the production points concern only the commercial nuclear power reactors and military applications, including nuclear weapons production and spent fuel from naval reactors (Figure 7).

The outside view makes it possible to track the various production points of radioactive materials. Additionally, it allows to deal with the interfaces between disposal systems and societal demands coming from the other compartments of society. In this view, however, disposal systems are seen as a "black-box" [32] with all the attributes of the inside view being aggregated together at the level $n$ (Figure 7). That is, the outside view is concerned about the changes that occur outside of the disposal system, independent from their technical, internal complexity. For example, the proposed societal metabolism representation can be used to assess and compare the viability and feasibility of different disposal strategies and policies in relation to energy transitions [60]. In this example, the energy supply sector must deal with the safe management of nuclear waste-in that case focusing on SNF from nuclear reactors-independently from the chosen pathways of energy transitions. Nuclear waste therefore represents a "biophysical overhead" affecting energy transitions. Conversely, decisions made about the energy systems, especially in the nuclear fuel cycle, directly affect the structures and functions of disposal systems. Especially, different nuclear fuel cycles will have different impacts on their back-end [61]. Adopting an integrated approach to the nuclear fuel cycle is necessary to address these interrelated constraints. Such integrated approach is particularly relevant as claims in favor of further deployment of nuclear power are now made on the basis of its sustainability in relation to energy-supply issues [62-64].

An important limitation of the outside view as presented in Figure 7 is that it represents a static view of disposal systems in their societal context. As such, it does not show the importance of the historical contingencies that drive much of the societal context of nuclear waste disposal. Changes can occur at different levels and at different times. For instance, the present representation of disposal systems at level $n$ reflects actions that occurred at other levels, such as the birth of the nuclear age and military applications at level $n+5$ ("Security" in Figure 7) during World War II, technical decisions at level $n+4$ ("Electricity") made in the 1950s, and, at level $n+2$ ("Nuclear power"), ethical decisions made by regulators in the 1970s, Congressional actions in the 1980s, and court decisions in the 1990s. The history of nuclear energy applications, particularly in the U.S., unfolded following a series of socio-technical imaginaries [66]. (In the field of science and technology studies (STS), the concept of 'sociotechnical imaginaries' refers to "collectively imagined forms of social life and social order reflected in the design and fulfillment of [ ... ] scientific and/or technological projects" ([66], p. 120).) Socio-technical imaginaries about nuclear power have been put forward by governments and industry about the dimensions of economic viability, environmental and health impacts, and intergenerational ethics [67]. Therefore, disposal systems that are being represented and/or designed now are the result of decisions made by past governments, utilities, private companies, regulators, and communities. For this reason, the definition of disposal systems considers those decisions to be external boundaries to the system. To represent those external factors directly affecting disposal systems at level $n$-although delayed in time-we present in Table 4 the types of decisions and institutions acting within the "Governance and control" (level $n+5)$ compartment and the "Nuclear power" (level $n+2)$ sector, as shown in Figure 7. 


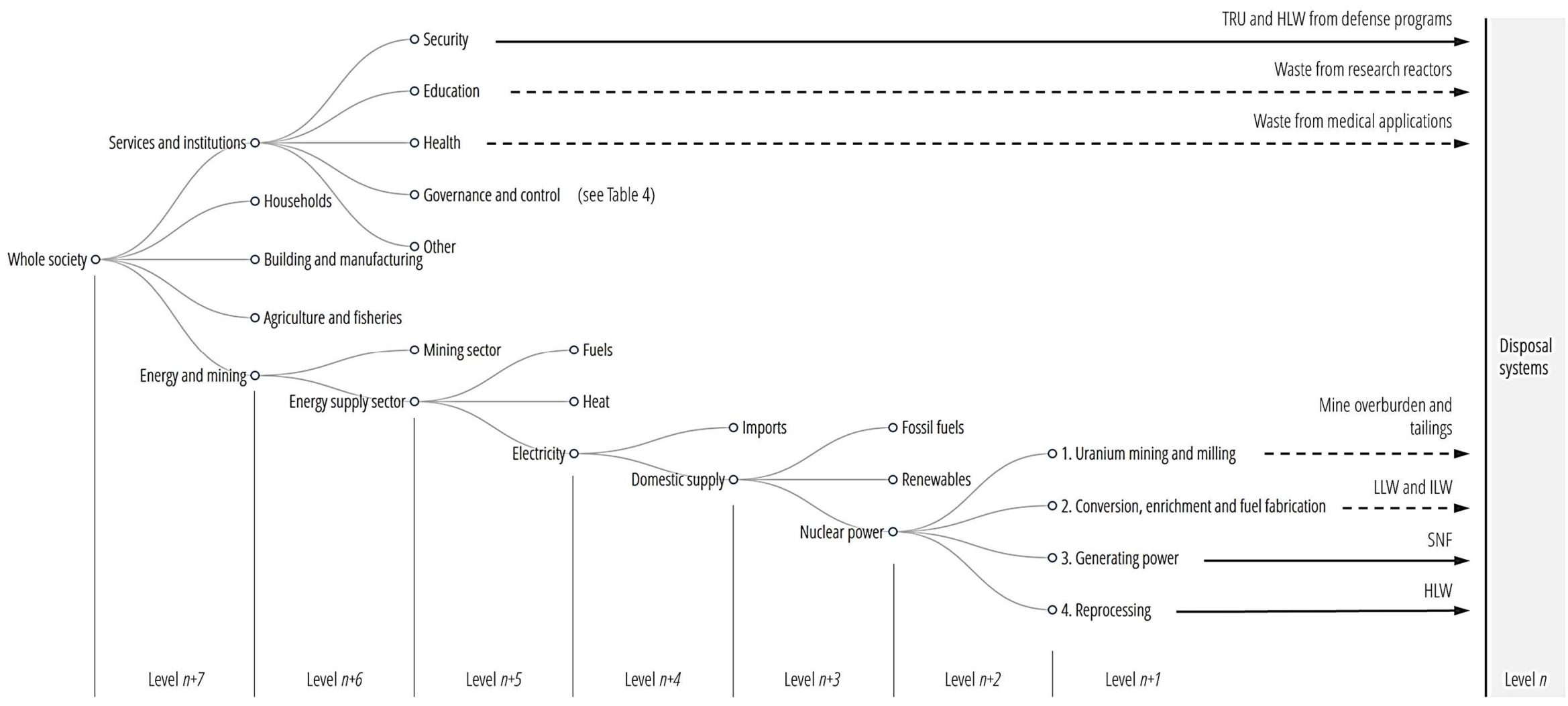

Figure 7. Outside view of nuclear waste disposal systems (levels $n / n+7$ ). The figure is based on the standard dendrogram used to represent energy systems [65] and nuclear energy systems [27] in the field of complex energetics [26]. Only the societal compartments (nodes) that are production points of radioactive waste requiring disposal are unfolded. Other nodes in the figure are "collapsed", i.e., their internal compartments are not shown. Plain lines correspond to radioactive materials requiring deep geological disposal. Doted lines correspond to other radioactive waste requiring storage and disposal not covered in this paper. Decisions within the "Governance and control" compartment and the "Nuclear power" sector that affect disposal systems are detailed in Table 4. Acronyms are provided in Appendix B. 
Table 4. The various types of institutions and decisions affecting nuclear waste disposal systems. Sources: $[13,27,28]$.

\begin{tabular}{|c|c|c|}
\hline Types of Institutions & Types of Decisions & Examples \\
\hline \multicolumn{3}{|c|}{ "Governance and control" (level $n+5)$} \\
\hline \multirow[t]{2}{*}{$\begin{array}{l}\text { Executive institutions } \\
\text { (governments) }\end{array}$} & $\begin{array}{l}\text { General decisions about } \\
\text { the nuclear fuel cycle }\end{array}$ & $\begin{array}{l}\text { Decision to implement a nuclear energy program; } \\
\text { absence or postponement of decision on spent fuel; } \\
\text { decision to reprocess and to directly dispose spent } \\
\text { fuel; decision to reprocess and recycle spent fuel; } \\
\text { decision to implement fast neutron reactors; decision } \\
\text { to implement partitioning and transmutation }\end{array}$ \\
\hline & $\begin{array}{l}\text { Implementation of the } \\
\text { nuclear waste disposal } \\
\text { strategies and policies }\end{array}$ & $\begin{array}{l}\text { Decrees applicable to licensing a deep geologic } \\
\text { repository; formal executive approvals required for } \\
\text { developing a deep geologic repository }\end{array}$ \\
\hline $\begin{array}{l}\text { Legislative institutions } \\
\text { (parliaments, senates, } \\
\text { house of representatives) }\end{array}$ & Legislation & $\begin{array}{l}\text { General legislation; regulations applicable to } \\
\text { licensing a deep geologic repository; formal } \\
\text { legislative approvals required for developing a deep } \\
\text { geologic repository; interactions with local } \\
\text { jurisdictions; type of decision-making process; } \\
\text { liabilities; funding mechanism }\end{array}$ \\
\hline $\begin{array}{l}\text { Regulatory authorities } \\
\text { (international, national, } \\
\text { state/local regulatory } \\
\text { authorities) }\end{array}$ & Regulation & $\begin{array}{l}\text { Compliance period; compliance boundary; } \\
\text { regulatory criteria }\end{array}$ \\
\hline $\begin{array}{l}\text { Civil society (general } \\
\text { public, local } \\
\text { governments, local } \\
\text { communities, political } \\
\text { parties, NGOs) }\end{array}$ & Indirect control & $\begin{array}{l}\text { Affects the decision-making process through } \\
\text { elections, public debate and local decisions }\end{array}$ \\
\hline \multicolumn{3}{|c|}{ “Nuclear power" (level $n+2$ ) } \\
\hline Utilities & Business & $\begin{array}{l}\text { Decisions related to generating power, including } \\
\text { reactor types, fuel types, fuel burnup rates, types of } \\
\text { spent fuel storage, and monitoring of spent fuel }\end{array}$ \\
\hline Other private companies & Business & $\begin{array}{l}\text { Decisions related to the front-end of the nuclear fuel } \\
\text { cycle, including mining and milling process, } \\
\text { enrichment technology, and fuel fabrication process }\end{array}$ \\
\hline
\end{tabular}

\subsubsection{Examples of Socio-Technical Interactions}

Isolating the technical definition of disposal systems from their societal context is a main assumption in any "integrated" formalism. This is because the requirement of deep geological disposal of highly-radioactive waste is fundamentally a societal decision imposed externally on the disposal systems. In fact, the very definition of the disposal systems is mainly the result of regulatory and legal frameworks. We present in this section two examples of how disposal systems are affected by societal demands. The first example from the Waste Isolation Pilot Plant (WIPP) in New Mexico shows the legal externality of labeling radioactive materials that later defines what is required to be disposed in deep geological repositories. This example illustrates how external, legal decisions can have endogenous effects on disposal systems. The second example about the proposed Yucca Mountain repository in Nevada illustrates how regulatory choices can impact the representation of deep geologic repositories. It illustrates how, seemingly conservative assumptions about extending the duration of the compliance period can result in adding unnecessary complexity in the models used to evaluate the performance of disposal systems.

We warn the reader about the length of this section. The two examples used to illustrate the challenges in the socio-technical integration of geological disposal systems necessarily include 
background information. The reader familiar with these two cases may skip this section and move directly to the discussion (Section 4).

Example \#1: Impacts of Change of Waste Types on Repository Design

In a recent editorial [3], the journal Nature suggested that it would be possible to reclassify some of the defense HLW as transuranic (TRU) waste (see Appendix A.1) so that the "reclassified" waste can be disposed of at the Waste Isolation Pilot Plant (WIPP) in New Mexico. The Nature editors explain [3]:

"Much high-level waste-produced during the reprocessing of spent nuclear fuel into plutonium - is highly radioactive and dangerous. But the evidence suggests that some of the waste that is labelled 'high level' technically qualifies as transuranic. This material is still barred from direct disposal at WIPP, purely because of how it was produced. But labels can be changed. If wastes that meet the transuranic criteria could be shipped to WIPP, it would save considerable time and effort as the DOE continues to struggle with the country's radioactive legacy."

The Nature editors claim that what is currently labelled as HLW in the U.S. depends on legal considerations, not on the composition and properties of the waste. The Nuclear Waste Policy Act (NWPA) of 1982 (Public Law 97-425) defines HLW as "highly radioactive material resulting from the reprocessing of spent nuclear fuel" [68]. Focusing on this legal definition could lead to different opinions about what can and cannot be classified as HLW from the nuclear-weapons program [69]. But the definition of HLW is more explicit than the law seems to indicate, since HLW generally contains large concentrations (typically, $10^{4}-10^{6} \mathrm{TBq} / \mathrm{m}^{3}$ ) of both short-lived and long-lived radionuclides. These radionuclides require a high-level of containment and isolation from humans and the environment to ensure long-term safety [70].

The Nature editors propose to change the NWPA's legal definition of HLW. This change would allow everything in the Hanford tanks that is not "highly radioactive" to be reclassified as anything other than HLW. Some of these "non-HLW" could then, in principle, be shipped to WIPP for disposal. The Nature editors' proposal actually refers to a decade-long effort by DOE to develop a technical and legal case to reclassify Hanford's tanks waste, which has received both technical and regulatory responses (see Appendix A.2). By removing the HLW label, much of the liquid waste at the Hanford site would be considered low-level waste (LLW), but some would have enough actinides to be considered TRU waste. In fact, the Washington State Department of Health currently considers up to 20 of the tanks to be TRU waste [69].

The "reclassify waste" proposal would have several socio-technical implications for the WIPP repository. First, it would extend its mission by increasing the disposal volume required. WIPP's capacity, as specified by the Land Withdrawal Act of 1992 (Public Law 102-579), is set to 6.2 million cubic feet $\left(176,000 \mathrm{~m}^{3}\right)$ of defense TRU waste by 2033 or earlier [71]. In 2014, a total of about 151,000 cubic meters $\left(\mathrm{m}^{3}\right)$ of TRU waste were expected to be disposed at WIPP. This would leave about $25,000 \mathrm{~m}^{3}$ theoretically available for disposal of other materials, but this number is likely to significantly decrease due to legal, regulatory, or technical factors (see Appendix A.3). Yet, approximately 32,000 $\mathrm{m}^{3}$ of vitrified defense HLW are expected to require geological disposal by 2048 (see Appendix A.1). The disposal of HLW at WIPP would therefore exceed the legislated capacity. To offset this problem, the capacity at WIPP could be increased. In this scenario, the iterations on the phases of planning and development would undoubtedly generate delays in the current operations at WIPP. Additional time would also be required for mining of additional disposal rooms and following disposal operations. Consequently, the repository closure currently planned for 2033 would be postponed by at least several decades. Significant postponement of the closure of WIPP would complicate the operation of repository because of the activation of salt creep. Salt creep can lead to deformation mechanisms in the repository before permanent closure (see Appendix A.4). Any postponement would require either additional access tunnels or structural reinforcements not anticipated in WIPP's original mission. 
Second, the "reclassify waste" proposal would also change WIPP's mission because vitrified HLW and TRU waste do not have the same compositions and properties. The Nature editors are correct in saying that "some of the waste that is labelled "high level' technically qualifies as transuranic" [3], although not legally. By "technically qualifies", the editors refer only to the technical part of the legal definition of TRU waste (i.e., concentration higher than $100 \mathrm{nCi} / \mathrm{g}$ of waste material) and not to the part that excludes waste otherwise defined to be HLW. However, the repository does not use the technical basis to define TRU. Instead, it uses the legal definition, which excludes all materials legally defined as HLW. Therefore, relabeling portions of defense HLW as TRU would not necessarily imply that they can be disposed of at WIPP. In fact, the Land Withdrawal Act of 1992 specifically bans HLW from WIPP. This explicit exclusion was meant to allay the State of New Mexico's concern that once WIPP was operating, it would attract other types of nuclear waste-as has occurred with the "reclassify" proposal [72]. Any material coming into WIPP would have to comply with the waste acceptance criteria (WAC) regulations, even if it classifies as "non-HLW." The WAC at WIPP provides requirements and associated criteria over all of the properties of each container but these requirements are for the facility and not necessarily the materials themselves. For instance, the WAC provides restrictions on the surface dose rate of TRU waste that may be accepted at WIPP; but these are not in the actual definition of TRU-they are legal attributes of WIPP rather than of TRU waste.

Therefore, the disposal of reclassified waste at the WIPP could have effects on the repository despite meeting the repository requirements set by the WIPP's WAC. The WAC currently authorizes an initial average heat output of up to $300 \mathrm{~W}$ per drum of TRU waste [73]. The WAC's average thermal output level limit would not allow the disposal of vitrified HLW canisters that exceed this limit (see Appendix A.1, Table A1). Yet, storing large amounts of heat-generating waste having an average heat output in the range of 60 to $300 \mathrm{~W}$ per canister could activate non-linear deformation of the salt (see Appendix A.4). Assessing the technical feasibility of disposing defense HLW at WIPP therefore requires a knowledge of the heat output of each canister being disposed. This would then be the basis for detailed studies of the non-linear effects on the salt caused by this thermal output. In addition to the radiological properties, the chemical composition of the waste would also vary between TRU waste and vitrified HLW. Although, HLW would have enough actinides to be considered TRU waste, it also contains significant amounts of fission products. Given their composition, the safety analysis of the WIPP repository would have to be revised to account for the very different geochemical mobilities of long-lived fission products found in HLW [42].

This example highlights some of the implications of disposing of defense HLW at WIPP under its current technical design, legal framework and regulatory requirements. In relation to technical implications, disposing of thermally hot HLW at WIPP would have important implications on the performance of the repository. A new mission for WIPP would therefore require going through the phases of repository planning and development. These would include the site's further characterization, extended licensing, and additional construction (in the situation an extension would be needed) and related operation works. At the legal level, this proposal would require the Land Withdrawal Act of 1992 be changed so that HLW and SNF could be disposed at WIPP and the State of New Mexico not opposing to an extension of the WIPP's operations. At the regulatory level, the current process specifically requires updating the 1996 WIPP Compliance Certification Application (CCA) to the U.S. Environmental Protection Agency (EPA) before making major changes in the disposal system. Any extended licensing for defense HLW at WIPP could create a major challenge. By law, the EPA regulates and certifies-rather than licenses-WIPP. But, also by law, the U.S. Nuclear Regulatory Commission (NRC) regulates and licenses disposal of HLW regardless of origin. Reconciling the regulatory responsibilities would introduce further complexity in the system (see Section 3.3.1).

In summary, the reclassification of waste by change in the law would imply changes in the regulatory framework, with ultimately technical implications at the repository level. In turn, these technical implications impacting the system design and disposal operations would have a feedback effect on the societal demands. For instance, there is not much doubt that a decision to implement the proposal to 
"reclassify waste" would stir public debate, probably impacting even further the U.S. nuclear waste management and disposal program. This example illustrates how policy recommendations to change one aspect (here the law) made in isolation from other constraints of disposal systems (technical feasibility and regulations) can potentially lead to counterproductive results.

\section{Example \#2: Impacts of Change of the Compliance Period}

The Energy Policy Act of 1992 directed the U.S. EPA and the U.S. NRC to develop a site-specific standard for a geological repository at Yucca Mountain in Nevada. The Act also required that the U.S. National Academy of Sciences (NAS) advise EPA on the appropriate technical basis for this standard [74]. NAS's National Research Council thus formed a special Committee on Technical Bases for Yucca Mountain Standards. In 1995, the Committee released its report defining the technical bases for the Yucca Mountain standards, including the time period of regulatory compliance necessary for a geological repository [75]. When the NAS study was conducted, the compliance period in the EPA standard-implemented by the NRC regulations-was 10,000 years. In the Academy report, however, the Committee concluded that there was "no scientific basis for limiting the time period of the individual risk standard to 10,000 years or any other value" ([75], p. 55). In the report, the Committee was going against the argument that beyond a certain period the epistemic uncertainties in compliance assessment become too large. They justified their view explaining that "compliance assessment is feasible for most physical and geologic aspects of repository performance on the timescale of the long-term stability of the fundamental geologic regime-a timescale that is on the order of $10^{6}$ years at Yucca Mountain" ([75], p. 6). The Committee thus considered the assessment feasible for much longer times than 10,000 years. However, it did not specify what the timespan of the compliance period should be. Instead, the Committee recommended "that compliance assessment be conducted for the time when the greatest risk occurs, within the limits imposed by long-term stability of the geologic environment" ([75], p. 7).

Following the NAS 1995 report, EPA promulgated in 2001 its revised safety standard that kept the 10,000-year compliance period. But in a lawsuit brought by the State of Nevada against the EPA, the U.S. Court of Appeals, in July 2004, remanded the EPA standard because it did not follow the Energy Policy Act of 1992. In order to comply with the court determination, the EPA revised the standard to require that the DOE consider the effects of climate change, volcanism, and seismic activity over a 1-million-year period. This decision contradicted the previous EPA and the NRC positions, which considered a compliance period of one million years not practical for regulatory decision-making [74].

The decision to extend the compliance period from 10,000 years to 1 million years had effects on the total system performance assessment supporting DOE's license application (TSPA-LA) for the Yucca Mountain repository. This decision changed the relative importance of model components used in the TSPA-LA. In Table 5, we compare the uncertain input parameters influencing uncertainty in response measures for the nominal scenario class in previous performance assessments conducted for the Yucca Mountain repository.

From Table 5, we see that under the previous EPA standard, the uncertainty in performance assessments was driven by the hydrology (geological processes) and rock properties (geological barriers), using the attributes of the integrated formalism presented in Section 3.1. The compliance period was first extended in 1999 to one million years as part of the performance assessment-viability assessment (PA-VA). Consequently, the uncertainty in the total system response became driven by the engineered barriers. This indicates that, all other things being equal, extending the compliance periods has changed the sensitivity analysis of the TSPA for the entire period of analysis. Shifting the compliance period from 10,000 years to one million years resulted in adding further complexity to the analysis. In fact, the TSPA had to also include the complex relations expected to occur during the geological period (see Figure 6d), which was not the case in previous performance assessments. 
Table 5. Comparison of the key parameters influencing uncertainty in response measures for the nominal scenario class in performance assessments for the Yucca Mountain disposal system. Source: after Table 2 of [76].

\begin{tabular}{|c|c|c|c|c|}
\hline PA & $\begin{array}{l}\text { Time } \\
\text { Period }\end{array}$ & Uncertain Parameter & $\begin{array}{l}\text { Model Component } \\
\text { (Sub-Component) }^{\text {(a) }}\end{array}$ & Level $n$-3 Attributes ${ }^{(b)}$ \\
\hline PA-EA & $10^{5}$ & $\begin{array}{l}\text { Percolation at repository } \\
\text { horizon }\end{array}$ & UZ-F (Site-scale UZ flow) & HYDRO, ROCK \\
\hline PA-91 & $10^{4}$ & $\begin{array}{l}\text { Percolation flux } 10 \mathrm{~m} \text { above } \\
\text { repository }\end{array}$ & UZ-F (Site-scale UZ flow) & HYDRO, ROCK \\
\hline PA-93 & $10^{4}$ & Percolation for arid climate & UZ-F (Site-scale UZ flow) & HYDRO, ROCK \\
\hline PA-95 & $10^{4}$ & $\begin{array}{l}\text { Matrix velocity in } \mathrm{CHnv} \\
\text { below repository at } 1.25 \\
\mathrm{~mm} / \text { year infiltration }\end{array}$ & UZ-F (Site-scale UZ flow) & HYDRO, ROCK \\
\hline PA-VA & $10^{4}$ & $\begin{array}{l}\text { Fraction of waste packages } \\
\text { with seepage }\end{array}$ & UZ-F (Drift seepage) & HYDRO, ROCK, STRUCT \\
\hline PA-SR & $10^{5}$ & $\begin{array}{l}\text { SCC stress profile for outer lid } \\
\text { of container }\end{array}$ & WP\&DS-D (WAPDEG) & WPACKAGE, STRUCT \\
\hline PA-LA & $10^{4}$ & $\begin{array}{l}\text { SCCTHRP_Fraction of yield } \\
\text { threshold for SCC initiation }\end{array}$ & WP\&DS-D (WAPDEG) & WPACKAGE, STRUCT \\
\hline
\end{tabular}

Abbreviations used: CHnv, Tuffaceous Beds of the Calico Hills, nonwelded vitric (hydrologic unit matrix); EA, environmental assessment; HYDRO, hydrology (part of the "geological processes" at level $n-2$, see Figure 1); LA, license application; PA, performance assessment; ROCK, host rock (part of the "geological barriers" at level $n$ - 2 , see Figure 1); SCC, stress corrosion cracking; SCCTHRP, residual stress threshold for SCC nucleation of Alloy 22; SR, site recommendation; STRUCT, structural barriers (part of the "engineered barriers" at level $n-2$, see Figure 1); UZ-F, unsaturated zone flow; VA, viability assessment; WAPDEG, WP and DS degradation; WP\&DS-D, waste package (WP) and drip shield (DS) degradation; WPACKAGE, waste package (part of the "engineered barriers" at level $n-2$, see Figure 1). Notes: (a) Model component where parameter is used (as would eventually exist in the PA-LA) as referred to in Table 3. ${ }^{(b)}$ Attributes at level $n-3$ of the integrated formalism. Correspondence with model components from Figure 3. Model components can involve several attributes/processes (see Section 3.2.1).

The Committee's arguments about the compliance period contained some implicit assumptions about the behavior of the Yucca Mountain repository not supported by the performance assessments. For instance, the Committee concluded in its report that the risk of humans facing peak radiation may not occur until tens to hundreds of thousands of years after repository closure, "or even farther into the future" ([75], p. 2). This was used to justify the extension of the compliance period so it encompasses the peak risk. But this relies on at least one fundamental assumption: that the geological environment will remain stable during the first one million years after repository closure. When discussing the timescale, the Committee recommended that calculation of the maximum risks of radiation releases be conducted whenever they occur as long as the geological conditions in the repository environment remain stable [75]. This assumes that the repository will behave following its nominal conditions, with no external event occurring before the peak dose is reached. The mean maximum dose was indeed shown by the TSPA supporting the license application to occur at around 720,000 years for the nominal scenario class ([47], Section 6). But this cannot be known in advance. The concept of time of maximum mean value (peak dose) largely depends on the assumptions made about the probability of occurrence and the effects on the repository of exogenous events. This results in not having enough confidence about the time and initiating process of the peak dose. For this reason, deciding on the compliance period cannot be based on considerations about encompassing the time of maximum risks. Therefore, the assumption that the geological environment will remain stable up to one million years does not appear satisfactory to decide what compliance period is required for the performance assessment of the repository.

This implicit assumption points to a deeper misconception about the ability of earth sciences to predict the long-term behavior of a geological repository. In this example, the Committee says: "In comparison with many other fields of science, earth scientists are accustomed to dealing with 
physical phenomena over long timescales. In this perspective even the longest times considered for repository performance models are not excessive" ([75], p. 71). This statement reveals the Committee's misconception about what earth scientists really think about their field. In a landmark 1978 report, the U.S. Geological Survey provided an earth-science perspective on geologic disposal of HLW: "Certainly, an assumption of the constancy of rates of geologic processes, namely substantive uniformitarianism, is open to question. The past rates of occurrence of geologic events and processes have varied widely over time and there appears to be no clear philosophical basis for determining rates for these events or processes in the future. Geology is basically a retrodictive rather than a predictive science" ([77], p. 11). Moreover, geologic predictions are affected by large, ultimately irreducible, epistemic uncertainties due to the effect of complex interactions among events and processes whose individual effects may be simple (see Sections 3.1 and 3.2).

The Academy report made another important assumption. It assumed that changes in the climate conditions at the surface would probably have little effect on the performance of the underground repository [75]. Yet, although climate change is an uncertain parameter in the TSPA-LA, it is expected to have effects on the repository for every time period after permanent closure (see Section 3.2.3). During the thermal period after closure (up to around $10^{3}$ years), the change to a monsoon climate will likely affect the hydrology of the system. Then, during the engineered barriers period (up to around $10^{4}$ years), the system will be perturbed by the hydrologic, geophysical, and geochemical effects caused by a glacial-transition climate. Finally, during the geological period (up to and beyond $10^{5}$ years), the possible interglacial, pluvial periods of the post-10,000-year climate will further increase the infiltration rates. Increased infiltration rates will affect the hydrologic, geophysical, and geochemical conditions of the repository. The Committee's assumption about climate change therefore appears to contradict the results of the TSPA-LA.

Given these problems, it is not clear what basis the Committee used to consider one million years as the timescale required to encompass the long-term geologic processes at Yucca Mountain [75]. As we have shown in Section 3.2.3, geological processes are involved at every time periods after repository closure (Figure 6). Contrary to what the Committee asserts, we do not consider that the scientific basis for performance assessment will be invalidated so that no useful information can be derived for after the geologic environment has changed [75]. Instead, knowledge about the future state of the repository is equally limited for every time period after closure. This is because the model outputs are sensitive to assumptions made about key epistemically uncertain input parameters. No qualitative assessment can be given as to whether epistemic uncertainties are worse at 1000 years, 10,000 years or one million years. Therefore, nothing can be said about the varying quality of the estimates over time. Similarly, the Committee also asserts that the compliance of the repository in the near term could be assessed with more confidence because uncertainty in parameters increases with time. But, in the TSPA-LA, ranges of values for aleatory and epistemic uncertain parameters have been applied equally to all periods. That is, a constant uncertainty was considered for during the entire compliance period. This misconception led the Committee to consider that "uncertainties in waste canister lifetimes might have a more significant effect on assessing performance in the initial 10,000 years than in performance in the range of 100,000 years" ([75], p. 72). However, the TSPA-LA showed that, instead, for the total system scenario class, the key uncertain input parameter related to the lifetime of waste packages matters equally to the total system model sensitivity as other uncertain parameters related to geological processes (Table 2.4-12 of [47]). And, in the initial 10,000 years, the uncertainty about the waste package that matters most is not its lifetime but the level of stress corrosion cracking that the waste package can sustain in the case of an early seismic event.

In summary, the NAS Committee's hypothesis of a fundamental geologic regime remaining stable up to about one million years-used later as a basis for introducing the one-million-year compliance period in the Yucca Mountain standards-is challenged by the results of the TSPA-LA performed to demonstrate compliance with this standard. 


\section{Discussion}

\subsection{Limitations of the Integrated Formalism}

\subsubsection{Limitations of the Technical Integration}

This paper is a conceptual analysis. Therefore, the integrated formalism presented in Section 3.1 does not provide a list of parameters and criteria that can be used to build a total system model, conduct analyses, or make specific recommendations about nuclear waste disposal strategies and policies. Nor is it intended to provide an exhaustive list of technical attributes. For instance, other processes, such as surface storage and transportation, that can affect the disposal strategy have not been included in the formalism. These processes occur outside of the disposal systems. Therefore, they should be included as outside attributes, as with societal constraints. Also, we did not account for the specific attributes of deep boreholes given that this option has only recently been considered. We also excluded from the formalism extraterrestrial events (e.g., meteorite impact) from the exogenous processes. Extraterrestrial events are considered to be very unlikely by regulators; e.g., they were estimated as having a probability less than $10^{-8}$ per year for the Yucca Mountain repository [78]. Additionally, the integrated formalism presented in Section 3.1 considers only technical attributes. As such, it does not include other relevant attributes specific to management practices, regulatory frameworks, and societal demands that equally affect nuclear waste disposal systems. Rather, the social complexity that results from those factors is considered as external boundaries or constraints, which represent the main limitation of the formalism.

A complete approach to disposal systems may prove useful at the high level of policy discussions. Yet, the proposed formalism cannot work in isolation from the lower-level, technical details. That is, although we presented interactions between aggregated processes and the model components in the example of the Yucca Mountain repository, the analysis is based on a bottom-up approach. This bottom-up approach refers to information transfer between the various model components used in the total system performance assessment. Therefore, the integrated formalism cannot be applied in abstract terms in order to have meaningful insight into disposal strategies and policies. Consequently, the integrated formalism can certainly serve to reveal techno-scientific issues that were not evident at the lower level of analysis or only through a mathematical description of the total system. But this formalism cannot replace the detailed technical analysis of the relevant processes. The integrated formalism is aimed to address the complexity of disposal systems in the techno-scientific and science-policy discussions. It is not a method that will advance the knowledge inside the various disciplines forming the scientific basis of nuclear waste management and disposal.

\subsubsection{Limitations of the Socio-Technical Integration}

We have shown the integration of the technical processes involved in disposal systems and their societal constraints. However, we have not delivered on the promise of socio-technical integration of nuclear waste disposal systems. There are two reasons for this. Theoretically, whereas the boundaries of the disposal systems are clear, the societal constraints acting as external boundaries to the systems are very complex. This is because "societal constraints" are a semantically open concept that is there is no limitation on what they include and how they change in time. The limits of using a mathematical formalism to model complex social dynamics are well known in science and technology studies [79-81]. For instance, laws can change because of political changes. Yet, political changes are driven by a set of (changing) preferences, values, and beliefs. Thus, the network of societal constraints is far too complex for any model - even conceptual—to be able to capture its structures and functions. Generally, models which rely on a necessarily limited set of parameters are said to be semantically closed. For this reason, they are unable to integrate unbounded social dimensions. What we presented, instead, is one possible organization of different categories of societal constraints 
and an illustration by two examples of how they have interacted with the technical dimensions of nuclear waste disposal systems.

The second reason that societal needs and technical solutions cannot be fully integrated is practical. Societal demands are complex and unbounded. Any framework that tentatively integrates both technical complexity and social complexity would thus result in the impossibility to make any informed decision. This is because technical performance and societal constraints are incommensurable to each other. That is, they cannot be reduced to one dimension supporting the search for an optimal solution without losing essential information. Even when one uses methods such as multi-criteria decision analysis (e.g., [12]), the choice of the relative weights given to criteria is ultimately the result of a subjective choice varying among the different stakeholder groups and even changing in time [55]. Moreover, the groups included in the decision-making process will be unequally qualified to assess the two main dimensions on which decision must be made. For instance, while analysts, experts and regulators may be able to assess the technical suitability of a proposed geological repository, they have no mandate to assess whether the proposed technical solution meets societal demands other than regulatory criteria. Conversely, local communities and other stakeholder groups not having the technical background ultimately cannot but trust the judgement of the analysts, reviewers and regulators who evaluate the quality of the technical basis and whether it meets the safety standard. Yet, any decision must be made under unavoidable, ultimately irreducible, epistemic uncertainties over key input parameters. For this reason, decisions about nuclear waste strategies and policies must be equally based on both technical and societal considerations. Given the limitations of the socio-technical integration, science-policy discussions on nuclear waste disposal must therefore simultaneously operate at the interfaces between policy and the science and engineering disciplines, as well as between policy and the relevant social sciences.

\subsection{Value of the Integrated Formalism}

The integrated formalism demonstrates the usefulness of considering the evolution of nuclear waste disposal systems across the various processes and time periods as part of a higher-level analysis. Considering disposal systems from a higher level of aggregation of the actual processes allows one to generate an overall understanding that cannot be achieved by relying only on a hierarchy of models that focus on specific technical details. Even a total system analysis focuses on the mathematical framework that connects those models, not on a high level of understanding of the system [82]. The integrated formalism complements the use of models in that it provides an understanding about the evolution of disposal systems across timescales and in connection with its broader societal context.

Through the example of the Yucca Mountain repository, we have shown that the level of complexity of geological disposal systems increases and then decreases following the expected evolution of the thermal pulse of the waste materials in time. A repository will have a different evolving trajectory depending on the processes involved and as a function of time. This evolution indicates that the distinct conceptual structures and computational organizations could be used in performance assessments of disposal systems to minimize the level of complexity that needs to be introduced into the models. In this alternative use of performance assessments, the main periods of the evolution of a repository-and their relevant processes-would first have to be identified. Then, the possible outcomes (release to the biosphere or dose to humans) would be estimated focusing only on the processes that have the greatest impact at the timescale under consideration. Such approach might lead to the definition of different safety standards, hence to different disposal strategies. For instance, the use of "cold" repositories would avoid the non-linear effects generated as a result of the heat pulse of the waste.

"Cutting through the complexity" by reducing the number of processes considered at each timescale of analysis would drive the strategy to simpler approaches that rely on less sophisticated models. In turn, it would reduce the types of uncertainties introduced in the projected performance of a repository. For instance, when analyzing the geological period at around $10^{5}$ years, the waste packages 
are considered to have failed (breached). Thus, the performance properties and probabilities of failure of waste packages do not have to be included in the analysis. The analysis thus can focus on other input parameters that drive the uncertainty at that specific scale. Simplifying performance assessments of disposal systems would certainly also improve the understanding by analysts and reviewers about how the systems are expected to behave and evolve [82]. Such approach would also improve the ability to communicate to decision-makers and the broader public the results of the analysis, thus to ultimately improve their level of confidence about the safety.

\subsection{Science-Policy Implications}

The two examples of socio-technical interactions presented in the paper revealed a fundamental problem: the difficulty to distinguish science from policy when discussing geological disposal systems. We hope to have shown enough evidence of the interdependent relations between the technical description of disposal systems and their broader social context. Consequently, because of this interdependence, there is an unavoidable paradox in discussing disposal systems. First, there is the challenge of connecting the technical analysis to its societal context because of the social complexity. But at the same time, it is evident that the technical description of a disposal system cannot be made in isolation from this societal context. Simply said, geologic disposal of nuclear waste is a technical issue for which the societal dimensions and expectations cannot be ignored.

\section{Conclusions}

The conceptual integrated formalism presented here demonstrates that the analysis of nuclear waste disposal systems requires one to connect the relevant processes from a technically complete, societal perspective. Understanding of geological disposal systems cannot be based only on detailed process-specific models or a mathematically-based total system analysis. An integrated analysis will unavoidably have to be based on conventional existing models. But it will also have to cope with the complexity of disposal systems.

This approach is part of a broader line of research that applies integrated analysis to complex technological systems. The value of an integrated analysis approach is that it allows the use a flexible information system where attributes can be tailored to different systems and contexts. Moreover, the use of a hierarchical organization of the attributes relevant to nuclear waste disposal through a metabolic representation is an effective strategy for understanding the complexity of disposal systems. The integrated formalism supports the complete, technical representation of disposal systems from a societal perspective. This representation can benefit both the policy analysts and non-specialists by providing a broader view of the various technical interdependencies between the main attributes of those systems. The technical representation can also be useful to the analysts and reviewers who can better map their own subjects of study within a broader technical description of the system. The conceptual integrated formalism is flexible enough so that it can be further refined to reach a higher degree of detail. It can also hierarchically organize functional, technical information and knowledge supporting the back-end integration of the nuclear fuel cycle [10,11].

We have shown that to more adequately study geologic disposal systems, at least two types of analysis are required: one that addresses the technical complexity and another that connects the impacts of the societal constraints on this technical complexity. When epistemic uncertainties are high, one must recognize that subjectivity—thus, values and preferences-ultimately drive the scientific understanding of the systems-as acknowledged by the U.S. National Research Council's Committee on Technical Bases for Yucca Mountain Standards [75]. These uncertainties therefore ultimately drive also the decisions that derive from this scientific understanding. Complex technological systems pose a unique science-policy challenge. Only a partial scientific knowledge can be produced and, yet, decisions must be made under unavoidable uncertainty. This challenge should probably impose more humility [83] on our strategies to successfully demonstrate the safety of permanent isolation of highly-radioactive materials from humans and the biosphere in deep, mined geological repository. 
Author Contributions: Conceptualization, F.D.-M.; Funding acquisition, F.D.-M. and R.C.E.; Methodology, F.D.-M.; Visualization, F.D.-M.; Writing—original draft, F.D.-M.; Writing-review \& editing, R.C.E.

Funding: The project leading to this publication has received funding from the European Union's Horizon 2020 research and innovation program under the Marie Sklodowska-Curie grant agreement No 739850, as well as from the MacArthur Foundation under the Nuclear Security Fellowship program of the Center for International Security and Cooperation (CISAC) at Stanford University. This work reflects the authors' view only; the funding agencies are not responsible for any use that may be made of the information it contains.

Acknowledgments: We are grateful to Peter N. Swift, Don Hancock, members of the Nuclear Reading Group at CISAC-Sannia Abdullah, Larry Brandt, Gabrielle Hecht, Siegfried Hecker, Chantell Murphy, Maxime Polleri, Cameron Tracy, and Kristin Ven Bruusgaard-as well as three anonymous reviewers for their useful comments, constructive criticism, and suggestions on earlier versions of this paper. We also acknowledge the help from Hilary Sun with an earlier version of the application (Section 3.2). An earlier version of this paper was presented by F.D.-M. in a public seminar entitled "A new perspective on nuclear waste management: facing the technical and social challenges of a complex science-policy issue" held at CISAC on 4 December 2017. We thank the audience for their feedback and constructive criticism, particularly Paul Edwards. Finally, we also thank members of the performance assessment team of Sandia National Laboratories in Albuquerque, New Mexico-Evaristo Bonano, Patrick Brady, Geoff Freeze, Clifford Hansen, Jon Helton, Elena Kalinina, Kurt Larson, Robert MacKinnon, Rob Rechard, David Sassani, David Sevougian, and Peter Swift-for useful discussions about the TSPA-LA of the Yucca Mountain repository during interviews conducted by F.D.-M. on 30-31 July 2018. The views expressed in this paper are the sole responsibility of the authors.

Conflicts of Interest: The authors declare no conflict of interest. The founding sponsors had no role in the design of the study; in the collection, analyses, or interpretation of data; in the writing of the manuscript, and in the decision to publish the results.

\section{Appendix A.}

This appendix presents background information for the example of socio-technical interactions "Example \#1: Impacts of change of waste types on repository design" presented in Section 3.3.3.

\section{Appendix A.1. Background Information on Defense High-Level Waste and Transuranic Waste}

The U.S. nuclear-weapons program from the 1940s through the late 1980s led to a legacy of radioactive materials [84]. TRU waste and defense HLW are among those radioactive materials for which permanent disposal is required [85]. Aqueous reprocessing of DOE's SNF was performed at the Hanford Site, Washington, the Idaho National Laboratory (INL), and the Savannah River Site (SRS), South Carolina [86]. Currently, defense HLW awaiting vitrification represent volumes of $207,000 \mathrm{~m}^{3}$ of liquid HLW stored in 177 underground tanks at the Hanford Site and $98,000 \mathrm{~m}^{3}$ at SRS (see Table A1). Liquid HLW is intended to be vitrified by separating the waste into a high-level waste stream for vitrification and geologic disposal (called "vitrified HLW") and a low-activity waste stream for vitrification and/or immobilization in a grout for near-surface disposal at the Hanford and SRS sites [87]. Disposal volume for the vitrified HLW obtained from liquid HLW is projected to be $14,089 \mathrm{~m}^{3}$ (10,586 canisters) at the Hanford Site and $6957 \mathrm{~m}^{3}$ (about 8200 canisters) at SRS in 2048 (Table A1). In addition to liquid waste from the Hanford and SRS sites, other types of waste are also planned to be vitrified. For instance, vitrification has been proposed as an alternative treatment for the calcined HLW currently stored at INL [86], adding a total of $10,000 \mathrm{~m}^{3}$ [88] to be ready for disposal by end of 2035 [87]. In total, a volume of about 32,000 $\mathrm{m}^{3}$ of vitrified defense HLW projected to 2048 could require geological disposal.

Table A1 shows the different existing and projected types of defense HLW in the U.S. 
Table A1. Present waste types and projected waste forms and thermal output of defense HLW in the U.S. Source: [89], unless otherwise noted.

\begin{tabular}{|c|c|c|c|c|}
\hline Waste Type & Present Quantity of Waste Type & $\begin{array}{l}\text { Projected Quantity of Waste } \\
\text { Packages in } 2048\end{array}$ & $\begin{array}{c}\text { Physical Description of } \\
\text { Projected Waste Type and } \\
\text { Waste Form }\end{array}$ & $\begin{array}{c}\text { Thermal Output of Projected } \\
\text { Waste Type in } 2048 \\
\text { (W/container) }\end{array}$ \\
\hline \multicolumn{5}{|c|}{ Existing defense HLW } \\
\hline SRS HLW tank waste & $\begin{array}{c}3600 \mathrm{~m}^{3} \text { of vitrified waste in canisters } \\
\text { (estimated) }^{(\text {a) }}\end{array}$ & $\begin{array}{l}4050 \text { canisters } \\
\text { (estimated) }^{(a)}\end{array}$ & glass in canisters & $\begin{array}{c}4 \text { to } 120 \mathrm{~W} / \text { canister (at time of } \\
\text { production, 1996-2012) }\end{array}$ \\
\hline FRG glass at Hanford & 34 canisters & 34 canisters & $\begin{array}{l}\text { glass in canisters (containing } \\
\text { strontium and cesium) }{ }^{(b)}\end{array}$ & $375 \mathrm{~W} /$ canister \\
\hline \multicolumn{5}{|c|}{ Projected defense HLW } \\
\hline Hanford tank waste & $\begin{array}{c}\sim 207,000 \mathrm{~m}^{3} \text { of reprocessing waste in } \\
\text { tanks }\end{array}$ & $\begin{array}{c}\text { 10,586 canisters of glass, } 3735 \mathrm{~kg} \\
\text { per canister (filled) }\end{array}$ & $\begin{array}{l}\text { glass in canisters } \\
\quad \text { (planned) }\end{array}$ & $360 \mathrm{~W} /$ canister \\
\hline SRS HLW tank waste & $\begin{array}{c}98,000 \mathrm{~m}^{3} \text { of reprocessing HLW in tanks } \\
\text { (estimated) }\end{array}$ & $\begin{array}{l}4150 \text { canisters } \\
\text { (estimated) }^{(a)}\end{array}$ & $\begin{array}{l}\text { glass in canisters } \\
\text { (planned) }\end{array}$ & $\begin{array}{c}\text { Up to } 500 \mathrm{~W} / \text { canister (at time of } \\
\text { production) }\end{array}$ \\
\hline Calcine waste at INL & $\begin{array}{c}4400 \mathrm{~m}^{3} \text { of solid granular material } \\
\text { (calcine) in six Calcine Solids Storage } \\
\text { Facility (CSSF) bin sets }\end{array}$ & 11,400 canisters (estimated) & $\begin{array}{l}\text { glass in canisters } \\
\text { (planned) }{ }^{(c)}\end{array}$ & $\begin{array}{l}1.2 \text { to } 15.4 \mathrm{~W} / \text { canister } \\
\text { (unknown time) }\end{array}$ \\
\hline $\begin{array}{l}\text { Cs/Sr capsules at } \\
\text { Hanford }\end{array}$ & $\begin{array}{c}1335 \text { Cs capsules, } 601 \text { Sr capsules stored } \\
\text { underwater }\end{array}$ & 340 canisters & $\begin{array}{l}\text { glass in canisters } \\
\quad \text { (planned) }(\mathrm{d})\end{array}$ & $349 \mathrm{~W} /$ canister \\
\hline $\begin{array}{l}\text { Sodium-bearing waste } \\
\text { (SBW) at INL }\end{array}$ & $3200 \mathrm{~m}^{3}$ of liquid waste in tanks & 688 canisters & $\begin{array}{l}\text { solids and powders in canisters } \\
\text { (planned })(\mathrm{e})\end{array}$ & $2.5 \mathrm{~W} /$ canister \\
\hline
\end{tabular}


Separately, TRU waste comes from the production of weapons and contains transuranium elements, mainly $\mathrm{Pu}$, in low concentrations. The TRU waste from weapons production results almost exclusively from the fabrication of plutonium weapons components, the recycling of plutonium from production scrap, residues, or retired weapons, as well as the chemical separation of plutonium [84]. The vast majority of weapon-produced TRU waste were originally stored or buried at five DOE sites located at the Idaho National Engineering Laboratory (INEL), the Los Alamos National Laboratories (LANL), New Mexico, the Hanford Site, Washington, the Savannah River Site (SRS), South Carolina, and the Rocky Flats Environmental Technology Site (RF), Colorado [84]. As of today, only the RF site has been closed and most of the actinides removed, accounting, however, for less than $2 \%$ of the weapon-produced TRU waste originally stored at all sites [84,94].

Appendix A.2. Background Information on DOE's "Reclassify Waste" Proposal

The reclassify proposal does not come from the scientific community as the Nature editorial would suggest. Rather, it has been a concrete proposal actively considered by DOE for more than a decade.

In March 2004, the Environmental Evaluation Group (EEG) organized a technical workshop about a specific proposal related to some Hanford tanks [69]. The EEG was established in 1978 with funds provided by DOE to the State of New Mexico and was in charge of WIPP's operation oversight until 2004. Following this workshop, the EEG was defunded by DOE and its responsibility moved to the New Mexico Environment Department (NMED) and EPA [69,95]. The workshop focused on technical issues related to the some of the tank waste at Hanford thought to meet WIPP's waste acceptance criteria [69]. During this workshop, representatives from DOE detailed that DOE had identified the contents of 20 tanks at Hanford as potential candidate for disposal at WIPP [69]. Shortly after the workshop, in July 2004, DOE submitted a permit modification request to the NMED asking to establish a procedure for approval of the disposal of TRU mixed waste from tanks that has ever been managed as HLW [96]. Specifically, the request proposed to restrict the exclusion from the WIPP Hazardous Waste Facility Permit only to "high-level radioactive waste, as defined in the WIPP Land Withdrawal Act", thus proposing to remove previous reference to "waste that has ever been managed as high-level waste and waste from tanks." Following this DOE's request and after a period of public comments, NMED issued a regulatory response that accepted the request but also added to the proposal a clause that effectively barred the possibility of defense HLW to come to WIPP by specifying the tanks from the Hanford, INL, and SRS sites that were subject to the exclusion. Later, in April 2013, DOE submitted a second permit modification request to NMED asking to change the 2004 exclusion provisions on which the NMED has still not decided to date, requesting instead that the Class 2 permit modification request be reissued as Class 3 because it is of significant public interest [97].

\section{Appendix A.3. Background Information on WIPPs Waste Acceptance Criteria and Current Mission}

The TRU waste materials to be disposed at WIPP mainly consist of clothing, tools and equipment from the nuclear-weapons program contaminated by elements heavier than uranium, i.e., with atomic numbers higher than 92 . These elements are alpha-emitting radionuclides of half-lives greater than 20 years and in concentration higher than $100 \mathrm{nCi} / \mathrm{g}$ of waste material. Depending on the external radiation dose rate measured at the surface of the waste containers, TRU waste are mainly "contact handled" (CH-TRU, $\leq 2 \mathrm{mSv} / \mathrm{h}$ ) with some being "remote handled" (RH-TRU, $>2 \mathrm{mSv} / \mathrm{h}$ ). Transuranic waste must comply with the waste acceptance criteria (WAC) to be disposed at WIPP. The WAC apply to the transportation, storage, and disposal of $\mathrm{CH}$ and $\mathrm{RH}$ TRU waste at WIPP. The WAC are based on a complex regulatory scheme involving the participation of the federal implementing agency, the Carlsbad Field Office of the U.S. Department of Energy (DOE); federal and state regulatory agencies, the U.S. Environmental Protection Agency (EPA), U.S. Nuclear Regulatory Commission (NRC), and the New Mexico Environment Department (NMED); as well as the U.S. Congress. In 2014, a total of about 151,000 cubic meters $\left(\mathrm{m}^{3}\right)$ of TRU waste were expected to be disposed at WIPP; whereas, the legislated 
limit on total volume per the 1992 Land Withdrawal Act is 6.2 million cubic feet $\left(176,000 \mathrm{~m}^{3}\right)$ [71], leaving about $25,000 \mathrm{~m}^{3}$ theoretically available for disposal of other materials. However, the stored, projected, and anticipated waste volumes for shipping and disposal at WIPP are subject to change due to legal, regulatory, or technical factors and, thus, need to be revised annually [71].

\section{Appendix A.4. Background Information on Effects of Heat on the WIPP Repository}

The effects of heat generated by the radioactive decay of short lived fission products found in HLW are important to repository response because temperature can activate and accelerate deformation mechanisms [77,98-100]. As salt deformation is dominated by plastic behavior at elevated temperatures, the heat pulse from the waste implies a faster creep rate which impacts the mechanism of room closure [101]. Deformation of salt has been shown to be very sensitive to temperature and stress. As the deformation mechanisms result from the evolution of the substructures, these substructural changes must be understood to characterize the evolution of the repository under temperature and stress. Under application of stress, the salt deformation takes the form of an increase of dislocation density. Under certain conditions, higher dislocation density leads to higher strain, called strain hardening. Besides, higher temperatures associated with deviatoric stress promotes the liberation of brine through the combined effect of heat and fractures in the rock. This enhances dry-out around the repository openings which can have positive effects on the long-term performance of the repository but negative effects during the pre-closure and early post-closure periods.

In the 1980s, the Sandia National Laboratories conducted several studies about the effect of heat on the WIPP repository [102]. These studies supported WIPP's Compliance Certification Application submitted by DOE in 1996 and certified by EPA in 1998 [71]. A first study on the RH-TRU waste to be disposed at WIPP considered the effects on the repository of the heat generated by the radioactive decay of short lived fission products [103]. First, the heat could enhance the formation of fractures in the rock around the waste disposal rooms (intact salt) or in the repository seals and backfill (crushed salt), creating possible pathways for the migration of contaminated brine beyond the regulatory boundary [104]. Second, the thermal convection initiated by the heat-generating waste could enhance the water-vapor transport in the gas phase followed by a re-condensation of the water vapor away from the waste and a possible migration of the water back to the disposal rooms and contact with the waste [105].

To determine the heat and thermal effects from RH-TRU on the performance of the repository, two specific studies were conducted in 1988 and 1993. The first study, based on a numeric simulation concluded that the thermal load added by the RH-TRU waste, assuming a heat output of $60 \mathrm{~W}$ per waste package (drum), had no significant impact on room response (creep) and was comparable to the room response for the isothermal case [106]. However, the simulation showed a high sensitivity of the results to changes in the initial conditions such as the power output of the containers or the disposition of the drums in the disposal rooms. Moreover, the simulation shown a non-linear room response when varying those conditions. For instance, applying a moderate increase in power output (100 W per drum) led to a minor increase in room closure compared with the baseline response; whereas, a larger (300 W per drum) led to a very large increase in room closure. Similarly, a small increase in drum spacing resulted in a large decrease in room closure, whereas doubling that spacing resulted in only a moderate additional decrease in room closure.

The second study was an in-situ experiment designed to be "near-reference" regarding anticipated thermal outputs, geometrical spacing and layout in the disposal rooms of the RH-TRU drums, the reference conditions being those current when the experiment program began [107]. The experiment included heater tests considering two heat output conditions (115 and $300 \mathrm{~W})$ and temperature was monitored over the 5-year period that the experiment lasted, from 1985 to 1990 [102]. The in situ heater tests resulted in a temperature increase of about $3-4{ }^{\circ} \mathrm{C}$ above ambient temperature of about $28^{\circ} \mathrm{C}$ under the $115 \mathrm{~W}$ condition and $7-9{ }^{\circ} \mathrm{C}$ above ambient under $300 \mathrm{~W}$, thus confirming the results of the numerical simulations. 
These two studies showed that a heat output of up to $300 \mathrm{~W}$ would lead to a temperature increase of less than $10{ }^{\circ} \mathrm{C}$ in the near-field over a five-year period, said to be insufficient to enhance the formation of fractures or to generate a significant amount of water vapor. DOE therefore concluded that the RH-TRU waste will have no significant impact on the performance of the WIPP repository, especially because the anticipated initial heat output from the RH-TRU waste was lower than $1 \mathrm{~W}$ per drum, well below the 60-300 W range covered by the studies [103]. WIPP's WAC currently authorize an initial average heat output of up to $300 \mathrm{~W}$ per drum.

\section{Appendix B.}

List of acronyms used in the paper.

\section{General acronyms}

$\begin{array}{ll}\text { CH-TRU } & \text { contact-handled transuranic waste } \\ \text { DOE } & \text { U.S. Department of Energy } \\ \text { EPA } & \text { U.S. Environmental Protection Agency } \\ \text { HLW } & \text { high-level waste } \\ \text { ILW } & \text { intermediate-level waste } \\ \text { INL } & \text { Idaho National Laboratory } \\ \text { INEL } & \text { Idaho National Engineering Laboratory } \\ \text { LA } & \text { license application } \\ \text { LANL } & \text { Los Alamos National Laboratories, New Mexico } \\ \text { LLW } & \text { low-level waste } \\ \text { LWA } & \text { Land Withdrawal Act } \\ \text { NAS } & \text { U.S. National Academy of Sciences } \\ \text { NMED } & \text { New Mexico Environment Department } \\ \text { NWPA } & \text { Nuclear Waste Policy Act } \\ \text { NRC } & \text { U.S. Nuclear Regulatory Commission } \\ \text { RF } & \text { Rocky Flats Environmental Technology Site, Colorado } \\ \text { RH-TRU } & \text { remote-handled transuranic waste } \\ \text { SAR } & \text { safety analysis report } \\ \text { SNF } & \text { spent nuclear fuel } \\ \text { SRS } & \text { Savannah River Site, South Carolina } \\ \text { THMC } & \text { thermal, hydrologic, mechanical, and chemical processes } \\ \text { TRU } & \text { transuranic waste } \\ \text { TSPA } & \text { total system performance assessment } \\ \text { WAC } & \text { waste acceptance criteria } \\ \text { WIPP } & \text { Waste Isolation Pilot Plant, New Mexico } \\ \end{array}$

Acronyms used in the integrated formalism

$\begin{array}{ll}\text { BIO } & \text { biosphere processes } \\ \text { CLIMA } & \text { climate change } \\ \text { ENG-B } & \text { engineered barriers } \\ \text { EXO-P } & \text { exogenous processes } \\ \text { GEO-B } & \text { geological barriers } \\ \text { GEO-P } & \text { geological processes } \\ \text { GEOCHEM } & \text { geochemical processes } \\ \text { GEOPHYS } & \text { geophysical processes } \\ \text { HUMAN } & \text { human intrusion } \\ \text { HYDRO } & \text { Hydrology } \\ \text { ROCK } & \text { host rock }\end{array}$




$\begin{array}{ll}\text { SEISM } & \text { seismic activity } \\ \text { STRUCT } & \text { structural barriers } \\ \text { VOLCA } & \text { Volcanism } \\ \text { WCOMP } & \text { waste composition } \\ \text { WFORM } & \text { waste forms } \\ \text { WPACKAGE } & \text { waste packages } \\ \text { WPROP } & \text { waste properties } \\ \text { WRAD } & \text { waste radioactivity } \\ \text { WTREAT } & \text { waste treatments } \\ \text { WTYPE } & \text { waste types }\end{array}$

Acronyms used in the TSPA-LA of the Yucca Mountain repository

$\begin{array}{ll}\text { BDCF } & \text { biosphere dose conversion factor } \\ \text { D\&M } & \begin{array}{l}\text { degradation and mobilization } \\ \text { drip shield }\end{array} \\ \text { DS } & \text { engineered barrier system } \\ \text { EBS } & \text { Flow } \\ \text { F } & \text { flow and transport } \\ \text { F\&T } & \text { saturated zone } \\ \text { SZ } & \text { Transport } \\ \text { T } & \text { unsaturated zone } \\ \text { UZ } & \text { WP and DS degradation } \\ \text { WAPDEG } & \text { waste form } \\ \text { WF } & \text { waste package } \\ \text { WP } & \end{array}$

\section{References}

1. U.S. Nuclear Waste Technical Review Board. Designing a Process for Selecting a Site for a Deep-Mined, Geologic Repository for High-Level Radioactive Waste and Spent Nuclear Fuel-Detailed Analysis; U.S. Nuclear Waste Technical Review Board: Arlington, VA, USA, 2015.

2. Alley, W.M.; Alley, R. Too Hot to Touch: The Problem of High-Level Nuclear Waste; Cambridge University Press: Cambridge, UK, 2012; ISBN 978-1-107-03011-4.

3. Editorial Reclassify waste to shift the nuclear landscape. Nat. News 2017, 550, 429. [CrossRef] [PubMed]

4. Macfarlane, A.; Ewing, R. Déjà vu for U.S. nuclear waste. Science 2017, 356, 1313. [CrossRef] [PubMed]

5. U.S. Government Accountability Office Nuclear Waste. DOE Needs a Comprehensive Strategy and Guidance on Computer Models that Support Environmental Cleanup Decisions; U.S. Government Accountability Office: Washington, DC, USA, 2011; p. 40.

6. U.S. Department of Energy. Integrated Waste Management and Consent-Based Siting; U.S. Department of Energy: Washington, DC, USA, 2016; p. 32.

7. Johnson, C.A. Radioactive Waste Management: A Bibliography for the Integrated Data Base Program; Oak Ridge National Lab.: Ridge, TN, USA, 1981.

8. U.S. Department of Energy. Integrated Data Base Report-1996: U.S. Spent Nuclear Fuel and Radioactive Waste Inventories, Projections, and Characteristics; U.S. Department of Energy: Washington, DC, USA, 1997; p. 263.

9. Banerjee, K. Foreword: Special issue on UNF-ST\&DARDS. Nucl. Technol. 2017. [CrossRef]

10. Rechard, R.P.; Price, L.L.; Kalinina, E.A. Integrating Management of Spent Nuclear Fuel from Generation to Disposal; Sandia National Laboratories: Albuquerque, NM, USA, 2015; p. 45.

11. Bonano, E.J.; Kalinina, E.A.; Swift, P.N. The Need for Integrating the Back End of the Nuclear Fuel Cycle in the United States of America. MRS Adv. 2018, 3, 991-1003. [CrossRef]

12. Schwenk-Ferrero, A.; Andrianov, A. Comparison and Screening of Nuclear Fuel Cycle Options in View of Sustainable Performance and Waste Management. Sustainability 2017, 9, 1623. [CrossRef]

13. Schwenk-Ferrero, A.; Andrianov, A. Nuclear Waste Management Decision-Making Support with MCDA. Sci. Technol. Nucl. Install. 2017, 2017, 9029406. [CrossRef] 
14. Kautsky, U.; Saetre, P.; Berglund, S.; Jaeschke, B.; Nordén, S.; Brandefelt, J.; Keesmann, S.; Näslund, J.-O.; Andersson, E. The impact of low and intermediate-level radioactive waste on humans and the environment over the next one hundred thousand years. J. Environ. Radioact. 2016, 151, 395-403. [CrossRef] [PubMed]

15. Kautsky, U.; Lindborg, T.; Valentin, J. A biosphere assessment of high-level radioactive waste disposal in Sweden. Radiat. Prot. Dosim. 2015, 164, 103-107. [CrossRef] [PubMed]

16. Berglund, S.; Kautsky, U.; Lindborg, T.; Selroos, J.-O. Integration of hydrological and ecological modelling for the assessment of a nuclear waste repository. Hydrogeol. J. 2009, 17, 95-113. [CrossRef]

17. Lee, C.-J.; Lee, K.J. Application of Bayesian network to the probabilistic risk assessment of nuclear waste disposal. Reliab. Eng. Syst. Saf. 2006, 91, 515-532. [CrossRef]

18. Fedra, K. Integrated risk assessment and management: Overview and state of the art. J. Hazard. Mater. 1998, 61, 5-22. [CrossRef]

19. Ewing, R.C. Long-term storage of spent nuclear fuel. Nat. Mater. 2015, 14, 252-257. [CrossRef] [PubMed]

20. Ewing, R.C.; Whittleston, R.A.; Yardley, B.W.D. Geological Disposal of Nuclear Waste: A Primer. Elements 2016, 12, 233-237. [CrossRef]

21. von Berlepsch, T.; Haverkamp, B. Salt as a Host Rock for the Geological Repository for Nuclear Waste. Elements 2016, 12, 257-262. [CrossRef]

22. Grambow, B. Geological Disposal of Radioactive Waste in Clay. Elements 2016, 12, 239-245. [CrossRef]

23. Hedin, A.; Olsson, O. Crystalline Rock as a Repository for Swedish Spent Nuclear Fuel. Elements 2016, 12, 247-252. [CrossRef]

24. Laverov, N.P.; Yudintsev, S.V.; Kochkin, B.T.; Malkovsky, V.I. The Russian Strategy of using Crystalline Rock as a Repository for Nuclear Waste. Elements 2016, 12, 253-256. [CrossRef]

25. Swift, P.N.; Bonano, E.J. Geological Disposal of Nuclear Waste in Tuff: Yucca Mountain (USA). Elements 2016, 12, 263-268. [CrossRef]

26. Diaz-Maurin, F.; Giampietro, M. Complex Systems and Energy. In Reference Module in Earth Systems and Environmental Sciences; Elsevier: Amsterdam, The Netherlands, 2013; ISBN 978-0-12-409548-9.

27. Diaz-Maurin, F.; Giampietro, M. A “Grammar" for assessing the performance of power-supply systems: Comparing nuclear energy to fossil energy. Energy 2013, 49, 162-177. [CrossRef]

28. U.S. Nuclear Waste Technical Review Board. Survey of National Programs for Managing High-Level Radioactive Waste and Spent Nuclear Fuel: A Report to Congress and the Secretary of Energy; U.S. Nuclear Waste Technical Review Board: Arlington, VA, USA, 2009.

29. OECD Nuclear Energy Agency. Methods for Safety Assessment of Geological Disposal Facilities for Radioactive Waste Outcomes of the NEA MeSA Initiative; OECD Publishing: Paris, France, 2012; ISBN 978-92-64-99190-3.

30. Hansen, C.W.; Birkholzer, J.T.; Blink, J.; Bryan, C.R.; Chen, Y.; Gross, M.B.; Hardin, E.; Houseworth, J.; Howard, R.; Jarek, R.; et al. Overview of total system model used for the 2008 performance assessment for the proposed high-level radioactive waste repository at Yucca Mountain, Nevada. Reliab. Eng. Syst. Saf. 2014, 122, 249-266. [CrossRef]

31. Giampietro, M.; Allen, T.F.H.; Mayumi, K. The epistemological predicament associated with purposive quantitative analysis. Ecol. Complex. 2006, 3, 307-327. [CrossRef]

32. Giampietro, M.; Mayumi, K.; Sorman, A.H. Energy Analysis for a Sustainable Future: Multi-Scale Integrated Analysis of Societal and Ecosystem Metabolism (Hardback); Routledge: New York, NY, USA, 2013; ISBN 978-0-415-53966-1.

33. Rosen, R. Anticipatory Systems: Philosophical, Mathematical and Methodological Foundations; Pergamon Press: New York, NY, USA, 1985.

34. Barabási, A.-L.; Albert, R. Emergence of Scaling in Random Networks. Science 1999, 286, 509-512. [CrossRef] [PubMed]

35. Varela, F.J.; Dupuy, J.-P. (Eds.) Contemporary Views on the Origin of Life, Mind and Society. In Understanding Origins; Boston Studies in the Philosophy and History of Science; Springer: Dordrecht, The Netherlands, 1992; ISBN 978-90-481-4090-9.

36. Cilliers, P. Complexity and Postmodernism Understanding Complex Systems; Routledge: London, UK; New York, NY, USA, 1998; ISBN 0-203-01225-9.

37. Oreskes, N.; Shrader-Frechette, K.; Belitz, K. Verification, Validation, and Confirmation of Numerical Models in the Earth Sciences. Science 1994, 263, 641-646. [CrossRef] [PubMed] 
38. Box, G.E.; Draper, N.R. Empirical Model-Building and Response Surfaces; Wiley: New York, NY, USA, 1987; Volume 424.

39. Giampietro, M.; Mayumi, K.; Ramos-Martin, J. Multi-scale integrated analysis of societal and ecosystem metabolism (MuSIASEM): Theoretical concepts and basic rationale. Energy 2009, 34, 313-322. [CrossRef]

40. U.S. Department of Energy. U.S. Fifth National Report for the Joint Convention on the Safety of Spent Fuel Management and on the Safety of Radioactive Waste Management; U.S. Department of Energy: Washington, DC, USA, 2014; p. 190.

41. World Nuclear Association Information Library on Nuclear Waste. Available online: http:/ /www.worldnuclear.org/information-library/nuclear-fuel-cycle/nuclear-wastes.aspx (accessed on 25 August 2017).

42. Hedin, A. Spent Nuclear Fuel-How Dangerous Is It? SKB: Stockholm, Sweden, 1997; p. 60.

43. Hjørland, B. Theories of knowledge organization-Theories of knowledge. Knowl. Organ. 2014, 40, $169-181$. [CrossRef]

44. U.S. Nuclear Regulatory Commission. Briefing by Nuclear Waste Technical Review Board (NWTRB). 1998. Available online: https:/ / www.nrc.gov/docs/ML1512/ML15121A773.pdf (accessed on 23 November 2018).

45. Shoesmith, D.W. Fuel corrosion processes under waste disposal conditions. J. Nucl. Mater. 2000, $282,1-31$. [CrossRef]

46. Sandia National Laboratories. Total System Performance Assessment Model/Analysis for the License Application; Sandia National Laboratories, OCRWM Lead Laboratory for Repository Systems: Las Vegas, NV, USA, 2008.

47. U.S. Department of Energy. Yucca Mountain Repository License Application: Safety Analysis Report; U.S. Department of Energy, Office of Civilian Radioactive Waste Management: Washington, DC, USA, 2008.

48. Helton, J.C.; Hansen, C.W.; Sallaberry, C.J. Conceptual structure and computational organization of the 2008 performance assessment for the proposed high-level radioactive waste repository at Yucca Mountain, Nevada. Reliab. Eng. Syst. Saf. 2014, 122, 223-248. [CrossRef]

49. Tsang, C.-F. (Ed.) Coupled Processes Associated with Nuclear Waste Repositories; Academic Press Inc.: Orlando, FL, USA, 1987; ISBN 0-12-701620-1.

50. OECD Nuclear Energy Agency. Post-Closure Safety Case for Geological Repositories-Nature and Purpose; Nuclear Energy Agency, Organisation for Economic Co-Operation and Development: Paris, France, 2004; ISBN 92-64-02075-6.

51. Porter, T.M. Trust in Numbers: The Pursuit of Objectivity in Science and Public Life; Princeton University Press: Princeton, NJ, USA, 1995; ISBN 978-1-4008-2161-7.

52. Jasanoff, S. The Fifth Branch: Science Advisers as Policymakers; Harvard University Press: Cambridge, MA, USA, 1990.

53. Collins, H.M.; Evans, R. Rethinking Expertise; University of Chicago Press: Chicago, IL, USA, 2007.

54. Munda, G. Social multi-criteria evaluation: Methodological foundations and operational consequences. Eur. J. Oper. Res. 2004, 158, 662-677. [CrossRef]

55. Munda, G. Social Multi-Criteria Evaluation for a Sustainable Economy; Springer: Berlin/Heidelberg, Germany, 2008; ISBN 978-3-540-73702-5.

56. Ewing, R.C.; Tierney, M.S.; Konikow, L.F.; Rechard, R.P. Performance Assessments of Nuclear Waste Repositories: A Dialogue on Their Value and Limitations. Risk Anal. 1999, 19, 933-958. [CrossRef] [PubMed]

57. Saltelli, A.; Giampietro, M. What is wrong with evidence based policy, and how can it be improved? Futures 2017, 91, 62-71. [CrossRef]

58. Giampietro, M.; Mayumi, K.; Sorman, A.H. The Metabolic Pattern of Societies: Where Economists Fall Short; Routledge: New York, NY, USA, 2012; ISBN 978-0-415-58953-6.

59. Giampietro, M.; Mayumi, K.; Martinez-Alier, J. Introduction to the special issues on societal metabolism: Blending new insights from complex system thinking with old insights from biophysical analyses of the economic process. Popul. Environ. 2000, 22, 97-108. [CrossRef]

60. Diaz-Maurin, F. The Viability and Desirability of Alternative Energy Sources: Exploring the Controversy over Nuclear Power. Ph.D. Thesis, Universitat Autònoma de Barcelona, Bellaterra, Spain, 2013.

61. Ewing, R.C. Environmental impact of the nuclear fuel cycle. In Energy, Waste and the Environment: A Geochemical Perspective; Gierié, R., Stille, P., Eds.; Geological Society: London, UK, 2004; Volume 236, pp. 7-23. 
62. Azapagic, A. Special issue on sustainability of nuclear power. Proc. Inst. Mech. Eng. Part J. Power Energy 2012, 226, 302-303. [CrossRef]

63. Solomon, B.D. Special Issue "Sustainability and Nuclear Power". 2016. Available online: http:/ /www.mdpi. com/journal/sustainability/special_issues/nuclear_power (accessed on 23 November 2018).

64. Poinssot, C.; Bourg, S.; Grandjean, S.; Boullis, B. The Sustainability, a Relevant Approach for Defining the Roadmap for Future Nuclear Fuel Cycles. Procedia Chem. 2016, 21, 536-544. [CrossRef]

65. Giampietro, M.; Diaz-Maurin, F. The Energy Grammar. In Resource Accounting for Sustainability Assessment: The Nexus between Energy, Food, Water and Land Use; Giampietro, M., Aspinall, R.J., Ramos-Martin, J., Bukkens, S.G.F., Eds.; Routledge Explorations in Sustainability and Governance; Routledge: New York, NY, USA, 2014; Chapter 8; pp. 90-115. ISBN 978-0-415-72059-5.

66. Jasanoff, S.; Kim, S.-H. Containing the Atom: Sociotechnical Imaginaries and Nuclear Power in the United States and South Korea. Minerva 2009, 47, 119. [CrossRef]

67. Diaz-Maurin, F.; Kovacic, Z. The unresolved controversy over nuclear power: A new approach from complexity theory. Glob. Environ. Chang. 2015, 31, 207-216. [CrossRef]

68. Nuclear Waste Policy Act of 1982 (Public Law 97-425). 1983. Available online: https://www.gpo.gov/fdsys / pkg/STATUTE-96/pdf/STATUTE-96-Pg2201.pdf (accessed on 23 November 2018).

69. Anastas, G.; Channel, J.K. Report on the March 16, 2004 Environmental Evaluation Group (EEG) Sponsored Workshop on the U.S. Department of Energy (DOE) Plans to dispose of Hanford High-Level Radioactive Waste at the Waste Isolation Pilot Plant (WIPP); Albuquerque, NM, USA, 2013; p. 13.

70. International Atomic Energy Agency Classification of Radioactive Waste; IAEA Safety Standards Series; International Atomic Energy Agency: Vienna, Austria, 2009; p. 48.

71. U.S. Department of Energy WIPP Compliance Recertification Application 2014, Section 24: Waste Characterization (40 CFR § 194.24); U.S. Department of Energy, Waste Isolation Pilot Plant: Carlsbad, NM, USA, 2014; p. 57.

72. Ewing, R.C. Correspondence: Gauging the risk from US nuclear waste. Nature 2017, 552. [CrossRef] [PubMed]

73. U.S. Department of Energy. Transuranic Waste Acceptance Criteria for the Waste Isolation Pilot Plant; U.S. Department of Energy: Washington, DC, USA, 2016; p. 123.

74. U.S. Nuclear Regulatory Commission. Definition of a Timespan of Regulatory Compliance for a Geological Repository at Yucca Mountain; U.S. Nuclear Regulatory Commission: Washington, DC, USA, 2005.

75. U.S. National Research Council. Technical Bases for Yucca Mountain Standards; The National Academies Press: Washington, DC, USA, 1995; ISBN 978-0-309-17633-0.

76. Rechard, R.P. Results from past performance assessments for the Yucca Mountain disposal system for spent nuclear fuel and high-level radioactive waste. Reliab. Eng. Syst. Saf. 2014, 122, 207-222. [CrossRef]

77. Bredehoeft, J.D.; England, A.; Stewart, D.; Trask, N.; Winograd, I. Geologic Disposal of High-Level Radioactive Wastes: Earth-Science Perspectives; U.S. Geological Survey Circular 779; U.S. Department of the Interior, U.S. Geological Survey: Alexandria, VA, USA, 1978.

78. Sandia National Laboratories. Features, Events, and Processes for the Total System Performance Assessment: Analyses; Sandia National Laboratories, OCRWM Lead Laboratory for Repository Systems: Las Vegas, NV, USA, 2008.

79. Jasanoff, S.; Markle, G.; Petersen, J.; Pinch, T. Handbook of Science and Technology Studies, Revised Edition; SAGE Publications, Inc.: Thousand Oaks, CA, USA, 1995.

80. Vespignani, A. Modelling dynamical processes in complex socio-technical systems. Nat. Phys. 2012, 8, 32-39. [CrossRef]

81. Weidlich, W. Sociodynamics: A Systematic Approach to Mathematical Modelling in the Social Sciences; Dover Publications, Inc.: Mineola, NY, USA, 2000; ISBN 978-0-486-45027-8.

82. Swift, P.N. 15-Safety assessment for deep geological disposal of high-level radioactive waste. In Geological Repository Systems for Safe Disposal of Spent Nuclear Fuels and Radioactive Waste, 2nd ed.; Apted, M.J., Ahn, J., Eds.; Woodhead Publishing Series in Energy; Woodhead Publishing: Cambridge, UK, 2017; pp. 451-473. ISBN 978-0-08-100642-9.

83. Jasanoff, S. Technologies of Humility: Citizen Participation in Governing Science. Minerva 2003, 41, $223-244$. [CrossRef] 
84. U.S. Department of Energy. Linking Legacies: Connecting the Cold War Nuclear Weapons Production Processes to Their Environmental Consequences; U.S. Department of Energy, Office of Environmental Management: Washington, DC, USA, 1997; p. 232.

85. Kok, K.D.; Heckman, J.; Devarakonda, M. Waste Disposal: Transuranic Waste, High-Level Waste and Spent Nuclear Fuel, and Low-Level Radioactive Waste. In Nuclear Engineering Handbook, 2nd ed.; Mechanical and Aerospace Engineering Series; CRC Press: Boca Raton, FL, USA, 2017; Chapter 16; pp. 521-555.

86. Carter, J.; Luptak, A.; Gastelum, J.; Stockman, C.; Miller, A. Fuel Cycle Potential Waste Inventory for Disposition; U.S. Department of Energy: Washington, DC, USA, 2012; p. 328.

87. U.S. National Research Council. Research Needs for High-Level Waste Stored in Tanks and Bins at U.S. Department of Energy Sites: Environmental Management Science Program; The National Academies Press: Washington, DC, USA, 2001; ISBN 978-0-309-07565-7.

88. U.S. National Research Council. Alternative High-Level Waste Treatments at the Idaho National Engineering and Environmental Laboratory; The National Academies Press: Washington, DC, USA, 1999; ISBN 978-0-309-06628-0.

89. Sandia National Laboratories. Evaluation of Options for Disposal of SNF and HLW; Sandia National Laboratories: Albuquerque, NM, USA, 2014; p. 8.

90. U.S. Department of Energy, Savannah River Remediation. Defense Waste Processing Facility Update; U.S. Department of Energy, Savannah River Remediation: Aiken, SC, USA, 2015.

91. U.S. Department of Energy, Savannah River Site. DOE's DWPF at SRS Pours 4,000th Canister of Vitrified Waste; News Savannah River Site; U.S. Department of Energy, Savannah River Site: Aiken, SC, USA, 2016.

92. U.S. Department of Energy. Savannah River Operations Office. 2017. Available online: https://www.admin. sc.gov/files/nac/DWPF\%20and\%20Liquid\%20Waste\%20Update.pdf (accessed on 23 November 2018).

93. U.S. Department of Energy, Savannah River Remediation. Defense Waste Processing Facility; U.S. Department of Energy, Savannah River Remediation: Aiken, SC, USA, 2017.

94. U.S. Department of Energy. Annual Transuranic Waste Inventory Report; U.S. Department of Energy, Waste Isolation Pilot Plant: Carlsbad, NM, USA, 2017; p. 424.

95. Butler, D. Call for better oversight of nuclear-waste storage. Nat. News 2014, 509, 267. [CrossRef] [PubMed]

96. U.S. Department of Energy. Class 2 Permit Modification Request, Procedure for Consideration of Tank Waste, Waste Isolation Pilot Plant, Carlsbad, New Mexico; WIPP HWFP No. NM489013908-TSDF; U.S. Department of Energy, Waste Isolation Pilot Plant: Carlsbad, NM, USA, 2004; p. 17.

97. U.S. Department of Energy. Class 2 Permit Modification Request, Modify Excluded Waste Prohibition, Waste Isolation Pilot Plant, Carlsbad, New Mexico; WIPP Permit Number NM4890139088-TSDF; U.S. Department of Energy, Waste Isolation Pilot Plant: Carlsbad, NM, USA, 2013; p. 111.

98. Hudson, J.A.; Stephansson, O.; Andersson, J.; Tsang, C.-F.; Jing, L. Coupled T-H-M issues relating to radioactive waste repository design and performance. Int. J. Rock Mech. Min. Sci. 2001, 38, 143-161. [CrossRef]

99. Rutqvist, J.; Barr, D.; Birkholzer, J.T.; Chijimatsu, M.; Kolditz, O.; Liu, Q.; Oda, Y.; Wang, W.; Zhang, C. Results from an International Simulation Study on Coupled Thermal, Hydrological, and Mechanical Processes near Geological Nuclear Waste Repositories. Nucl. Technol. 2008, 163, 101-109. [CrossRef]

100. Heierli, J.; Genoni, O. The Role of Temperature in the Safety Case for High-Level Radioactive Waste Disposal: A Comparison of Design Concepts. Geosciences 2017, 7, 42. [CrossRef]

101. Hansen, F.D.; Leigh, C.D. Salt Disposal of Heat-Generating Nuclear Waste; Sandia National Laboratories: Albuquerque, NM, USA, 2011; p. 101.

102. Kuhlman, K.L. Radwaste Solutions; American Nuclear Society: La Grange Park, IL, USA, 2013; pp. 22-28.

103. U.S. Department of Energy. WIPP Remote-Handled Transuranic Waste Study; U.S. Department of Energy, Waste Isolation Pilot Plant: Carlsbad, NM, USA, 1995; p. 124.

104. Galson, D.A.; Hicks, T.W.; Wilmont, R.D.; Swift, P.N. Systems Prioritization Method-Iteration 2, Baseline Position Paper: Scenario Development for Long-Term Performance Assessments of the WIPP; Sandia National Laboratories: Albuquerque, NM, USA, 1995.

105. Butcher, B.M.; Webb, S.W.; Berglund, J.W.; Johnson, P.R. Systems Prioritization Method-Iteration 2, Baseline Position Paper: Disposal Room and Cuttings Models; Sandia National Laboratories: Albuquerque, NM, USA, 1995; Volume I. 
106. Argüello, J.G.; Torres, T.M. Thermal Effects of RH-TRU [Remote Handled Transuranic] Waste Emplacement on WIPP Storage Room Thermal/Structural Response; Sandia National Laboratories: Albuquerque, NM, USA, 1988.

107. Molecke, M.A.; Argüello, J.G.; Beraún, R. Waste Isolation Pilot Plant Simulated RH TRU Waste Experiments: Data and Interpretation Report; Sandia National Laboratories: Albuquerque, NM, USA, 1993. 